\title{
Ratios of biogenic elements for distinguishing recent from fossil microorganisms
}

\author{
Richard B. Heover \\ Astrobiology Laboratory, \\ NASA/Marshall Space Flight Center, \\ National Space Science and Technology Center, \\ 320 Sparkman Dr., Huntsville, AL 35805 USA
}

\begin{abstract}
The ability to distinguish possible microfossils from recent biological contaminants is of great importance to Astrobiology. In this paper we discuss the application of the ratios of life critical biogenic elements $(\mathrm{C} / \mathrm{O} ; \mathrm{C} / \mathrm{N}$; and $\mathrm{C} / \mathrm{S}$ ) as determined by Energy Dispersive X-ray Spectroscopy (EDS) to this problem. Biogenic element ratios will be provided for a wide variety of living cyanobacteria and other microbial extremophiles, preserved herbarium materials, and ancient biota from the Antarctic Ice Cores and Siberian and Alaskan Permafrost for comparison with megafossils and microfossil in ancient terrestrial roeks and carbonaceous meteorites.
\end{abstract}

KEYWORDS: Microfossils, Carbonaceous Meteorites, Orgueil, Murchison, Energy Dispersive X-Ray Spectroscopy; Biomarkers, Biogenic Elements, Elemental Ratios, Cyanobacteria, Extremophiles

\section{INTRODUCTION}

Astrobiologists have highlighted the importance of establishing the validity of chemical, mineralogical and morphological bionarkers in ancient rocks, meteorites and other Astromaterials. It is necessary to recognize that biomarkers exist in a variety of strength levels. Weak biomarkers only suggest biogenicity whereas strong, valid biomarkers provide clear evidence of biological activity. Valid biomarkers in ancient rocks, meteorites and other astromaterials must satisfy rigorous criteria. During the past decade, extensive Field Emission (FESEM) and Environmental (GSEM) Scanning Flectron Microscopy investigations of the morphological characteristics and EDS analyses of the elemental compositions of minerals, terrestrial microfossils and known biological organisms have been investigated in the NASA/MSFC/NSSTC. Astrobiology Laboratory. These studies included a wide variety of minerals, rocks, and meteorites as well as living and fossil (Holocene to Archaean $2.8 \mathrm{Ga}$ ) eukaryotic and prokaryotic organisms (e.g., plants, hair, fungi, diatoms and other algae, cyanobacteria, sulfur and sulfate reducing bacteria. This research has resulted in the recognition that elemental ratios of certain life-critical biogenic elements can provide a powerful mechanism for distinguishing recent biological contaminants from ancient indigenons microfossils and recognizing valid morphological bionarkets in meteorites. This paper addresses the use of ratios of life critical biogenic elements ( $C, N$, and $S$ ) for distinguishing recent biological contaninants from valid, indigenous microfossils in ancient rocks and meteorites. To be considered valid, the biomarkers must satisfy to rigorous criteria:

1.) Valid biomarker must be Unambiguously Mtological

2.) Valid biomarkers must be Undeniably Indigenous

Although many biominerals provide weak evidence of biogenicity, some can be considered strong biomarkers. These mclude conchsively recognizable biofilms; biogenic magnetites and magnetosomes in "chain of pearls" configurations. Other mineral biomarkers include silica biopolymers such as are found in the shell of diatoms, silicoflagellates, and fadiolaria. More definitive evidence of biologieal aetivity is provided by valid bionarkers such as complex isoprenoid biomolectles, fatty acids, cholestame Pristane. Phytane and the diagenetic breakdown products 
of other biological pigments and protein Amino Acids with unambiguous enantiomeric excess. Valid biomarkers also would include segments of RNA, DNA, genes, proteins, enzymes, or other complex biomolecules as well and unambiguously recognizable microfossils or consontia with distinctive chemieal and cellular differentiation. It is crucial that the indigeneity of the biomarkers can be undeniably established. For this reason methodologies must be developed to distinguish recent biological contaminants from valid indigenous chemical and morphological biomarkers and microfossils in ancient rocks, meteonites and returned astromaterials.

Many important chemical biomankers have been detected in carbonaceous meteorites during stadies carried out by different investigators on a carbonaceous meteorite samples studied from the late-1800's to the present. Table I is a chronological summary for many chemical biomarkers detected in carbonaceous meteorites.

\section{TABLE I. Chemical Biomarkers in Carbonaceons Meteorites}

\begin{tabular}{|c|c|}
\hline BIOMARKER & REFERENCE \\
\hline Organic Matter $\sim$ humus, peat \& lignite coal ${ }^{13}$ & Cloez, 1864a, 1864b; Pisani, 1864 \\
\hline Petroleum-Hike Aydrocarbons & Berthelot, 1868 \\
\hline Amino Acids ${ }^{5-7}$ & Nagy et at., 1961, Kuenvolden et al., 1970 \\
\hline Long-Chain Fatty Acids Ancient Sediments ${ }^{8}$ & Nagy and Bik, 1963 \\
\hline Porphyrins & Hodgson and Baker, $1964 ; 1969$ \\
\hline Polymeric Matter $\sim$ Kerogen ${ }^{\text {T }}$ & Bitz and Nagy, 1966 \\
\hline Polyeyclic Aromatic Hydrocarbons & Commins and Harrington, 1966 \\
\hline Allphatic Aydrocarbons w/Alkane Preference ${ }^{13}$ & Nooner and Oro, 1967 \\
\hline Normal \& Isoprenoid alkanes ${ }^{16}$ & Gelpi \& Oro, 1970 \\
\hline $\begin{array}{l}\text { Nitrogen Heteregelies \& Nuclele Adid Bases Purines, } \\
\text { Pyrinidines Triagines, Adenine/Uraeil }\end{array}$ & $\begin{array}{l}\text { Hayatsu, et al. 1964, } 1968 \text {, Folsomme et al. 1973; } \\
\text { Hua et al., 1986; Stoks \& Schwartz, } 198\end{array}$ \\
\hline Pristane, Phytane and NorPristane ${ }^{13,26}$ & Nooner and Oro, 1967; Kissin, 2003 \\
\hline Protein Amino Acids with Canationeric Excess ${ }^{21-29}$ & $\begin{array}{l}\text { Oró et al., 1971; Engel et al.; 1980, 2003; Cronin et } \\
\text { al. 1997; Ehrenfreund et at., } 2001 \text {. }\end{array}$ \\
\hline
\end{tabular}

Some of these chemical biomarkers (e.g. PAH's, Petroleum-like Hydropearbons, Amino Acids, etc) can be produced by abiotic mechanisms (e.g., Miller-Urey or Fisher-Tropsch synthesis) and they consequently do not provide conclusive evidence of biological activity. However, many of the others are not produced by any known abiotic mechanisms and thus must be considered to represent valid chemical biomarkets in carbonaceots meteorites.

In 1967, Nooner and Oro ${ }^{13}$ detected isoprenoids (Pristane, Phytane and Norpristane) in the Orgueil CI1 carbonaceous meteorite. Pristane $(2,6,10,14$-tetramethylpentadectane) is a naturally saturated terpenpoid alkane $\left(\mathrm{C}_{19} \mathrm{H}_{40}\right)$ that is a biogeodiemiond derivative from phytol. Phytol is a well-known a deconnosition product of Chlorophyll. This photosynthetic pigment, which is crueial for the complex process of photosynthesis, ts common in phototrophic organisms on Earth. It plays a critical role in the flow of energy in the Biosphere. Phototrophs use trapped solar energy to convert carbon dioxide and water into sugars and nore complex cellulat components such as carbohydrates, polysaccharide sheaths, fatty acids, nucleic acids, DNA, RNA and a host of other biochemicals essential for life. The organic carbon that is fixed from carbon dioxide can then be used by other life forms. The stored solar energy is extracted by chemotrophic organisms via anaerobic fementation ptocesses that occur in the absence of oxygen, During aerobic zespiration the organio ourbon is completely oxidized and returned to the atmosphere as carbon dioxide, thereby completing the carbon eycle. Every carbon atom in every molectle in the organism is derived from carbon dioxide that is fxed into organic earbon by the photosynthetic process.

There are no known abiotic mechanisms that produce Chlorophyll. Pristane and Phytane are diagenetic derivative breakdown products of chlorophyll and are considered valid biomarkers. Kissin ${ }^{20}$ has pointed out that the transformation of chlorophyll into its phyto chain and then to the isoprenoid alkanes pristine and phytane is a slow process. Phytane $(3,7,11,15$-tetramethylhexadecane) is only found on Earth in anoient oil shales and crade petroleum. The conversion of terrestrial biological matter into linear alkyl chains is a slow, multi-step process involving microbialy mediated enzymatio reaetions. Kissiti's expentmental investigations established that the free saturated hydrocarbons in the Orgueil meteorite were not the result of contanination by oils used in the laboratory environnent or recent microbiolocical contamination effects. 


\section{Biogenic Elements in Living Organisms and Meteorites}

All organisms on Earth appear to possess the same fundamental requirements for liquid water, an energy source and requirement for a limited set of life-critical (biogenic) elements. By far the most critical elements in life on Earth are the six life critical elements (Carbon, Hydrogen, Oxygen, Nitrogen, Phosphorus, and Sulfur) are found in relatively large quantities in all organisms. The furst four are by far the most abindant. Sulfur and Phosphorus are also critical for life, but they are found in mueh smaller quantities in living organisms. Minor biogenic elements present in organisms in lesser amounts include: $\mathrm{Mg}, \mathrm{Fe}, \mathrm{Na}, \mathrm{K}, \mathrm{Ca}$, and $\mathrm{Cl}$. Biogenic elements are needed for construction of cellular struetural components, metabolism and respiration, and storage and transpert of energy and information. A few other elements (e,g, $\mathrm{Si}, \mathrm{Mn}, \mathrm{Al}, \mathrm{I}, \mathrm{Cu}, \mathrm{Zn}, \mathrm{As}, \mathrm{Ni}$ and $\mathrm{F}$ ) are needed for enzymatic actions and specialized functions and they usually appear only in trace levels.

All of the major life-critical biogenic elements (along with $\mathrm{Fe}, \mathrm{Si}$, and $\mathrm{Mg}$ ) are also the major components of both carbonaceous meteorites and comets. Comets may have played a major role in the dispersal of the biogenic elements throughout the Solar System. ${ }^{30,34}$ All are found in the Orgueit, Murchison and other carbonaceous meteorites. The distributions of the major biogente elements within the meteorite samples are very heterogeneous. Energy Dispersive X-Ray Spectroscopy (EDS) spot analysis and 2-D X-ray maps obtained during the present investigation clearly establish that the biogenic elements $\mathrm{C}, \mathrm{O}, \mathrm{Mg}$, and $\mathrm{S}$ are heavily concentrated in the filaments found in the Orgueil Cll carbonaceous meteorite. Furthermore, there is a teadily observable differentiation in abundances of the biogenic elements from observably different and distinguishable components of the filaments

Nitrogen is very rarely found to be present in the filarnents above the level of detectability of the EDS. Nitrogen is absolutely essential for life since it is present it all amino acids and in the puritues (Aderine and Guanine) and Pyrimidines (Cytesine, Uraol, and Thymine) which are essential for the oonstruction of life critical biomolecules such as ATP, RNA, DNA and proteins. All modern (and old but not fossilized) biological materials studied have been found to have detectable levels of nitrogen. However, nitrogen is absent in many ancient fossils as a result of the diagenetic losses that occur over many millions of years.

\subsection{Carbon in carbonacenus meteorites and filamentous microfossils}

Mason ${ }^{32}$ reported in 1963 that carbonaceous meteorites can contain up to $4,8 \%$ (weight \%) carbon. Otting and Zahringer ${ }^{33}$ obtained a slightly lower value $(3.19$ wt \%). Using the more sensitive Energy Loss Electron Spectrometer (EELS), the bulk Carbon content of the Orgueil meteorite was found to be $3.5 \%$ (by weight) and they found $5 \%$ of the earbon rich grains to also be enriched in Oxygen, Phosphorus and Sulfur (the COPS phase) ${ }^{34}$ The Biosphere is critically dependent upon "carbon fixation" reactions. In this complex processes enzymes are used to catalytically convert atmospheric $\mathrm{CO}_{2}$ into carbohydrates that can be used by living organisms. During the carbon fixation cycle, light energy is captured during photosynthesis by photoautotrophic microorganisms and stored in the chemical bonds of ATP and NADP. This stored energy can then be used to power the enzymatic reactions that convert molecules of earbon dioxide and water into the organic molecules. During the Calvin cycle in living organisms the fixation of $\mathrm{CO}_{2}$ into carbohydrates is catalyzed by the (RuBisCo) enzyme. ${ }^{35}$ The RuBisCo enzyme has both carboxylase and oxygenase activity and is also capable of fixing atmospheric oxygen during the process of photorespiration. RuBisco comprises almose $50 \%$ of the protein of chloroplasts and is thought to be the most abundant protein on Earth. Many bacteria and archaea are chemoautotrophs or chemolithotrophs that are capable of deriving energy from inorganic energy sources and chemical reactions and synthesizing organic compounds from carbon dioxide or carbonate rocks. Biologioal fractionation oceurs during the Calvin cyole since the light carbon stable isotope $\left(\mathrm{C}^{12}\right)$ is incorporated in preference to the heavier $\left(\mathrm{C}^{\text {t3 }}\right)$ isotope. Carbon isotope treasurements for glycine in the Orgneil meteorite yielded a value of $8^{13} \mathrm{C}=+22$ per mil (far above the terrestrial range of -20 to -35 per mil providing clear and convincing evidence that the Orgueil annino acids are extraterrestrial ${ }^{36}$ Biological fractionation of stable isotopes of carbon as seen in anctent long chain carbon biogeopolymers (kerogen) has been interpreted as geological evidence of biological activity preserved in the rock record for -3.8 Ga. Stromatolites formed by filamentous prokaryotes and cyanobacteria extend back to at least $2.8 \mathrm{Ga}^{37-41}$

\subsection{Oxygen th the carbonaceous metcorites and filamentous microfossils}

Oxygen is a hife-critical biogenic component of virtually all organic molecules, RNA, DNA and proteins and it is crucial for metabolism. The Orgueil and Murchison meteorites are rich in oxygen. The mean oxygen content for 
CI meteorites is $46 \% .{ }^{4}$ The EDS spot analysis reveals that some of the filaments have Oxygen levels above $60 \%$ (atomic) while others have values as low as $9 \%$ atomic. Some of the sheaths have $\mathrm{C} / \mathrm{O}$ ratios similar to kerogen. For example $\mathrm{C} / \mathrm{O}=108$ at spot $\mathrm{X}$ on the sheath of the graphitized filameatous miorofossil in Fig. 2.a. This ratio is entirely unlike that obtained for living or tecently dead biological matter. Elemental 2-D x-ray maps show many of the other filaments often have oxygen levels that significantly exceed the levels found in the adjacent or underlying rock matrix.

\subsection{Nitrogen in the Blosphere}

The Biosphere is critically dependent upon both "earbon fixation" and "nitrogen fixation" reactions. In these complex processes enzymes are used to catalytically convert atmospheric $\mathrm{CO}_{2}$ and $\mathrm{N}_{2}$ into forms that are useful to living organisms. Nitrogen is one of the most abundant elements in the Solar System and it critical to all living organisms. Nitrogen is an essential component of amino deids, nucleic acids, purines, pyrimidines, ATP and proteins. Nitrogen is required for synthesis of RNA and DNA and the regulation of many crucial biochemical pathways. Although nitrogen is abundant in the atmosphere $(79 \%)$, atmospheric nitrogen canot be used by living organisms until it has been converted by "nitrogen fixation" enzymatic processes. The $\mathrm{N}_{2}$ gas molecule is unavailable for most organisms due to the triple bond that renders it virtually inert. Nitrogen is converted into a useable state by nitrogen fixing bacteria such as the heterocystous cyanobacteria. The process of nitrogen fixation involves the conversion of gaseous dinitrogen into ammonia $\mathrm{NH}_{4}{ }^{+}$, which can then be converted to nitrite or ritrate ions by nitrifying bacteria. Nitrogen fixation is accomplished by use of the enzyme complex nitrogenase which catalyzes the reaction:

$$
\mathrm{N}_{2}+8 \mathrm{e}^{-}+8 \mathrm{H}^{+}+16 \mathrm{MgATP} \rightarrow 2 \mathrm{NH}_{3}+\mathrm{H}_{2}+16 \mathrm{MgATP}+16 \mathrm{P}
$$

Fixed nitrogen is precious and is scavenged after death by mictoorganisms and subsequently tonoved by a very slow diagenetic processes. Although the level of nitrogen can be fairly high ( 2 to $15 \%$ in living and dead modern biological materials, it is almost never encountered at levels above $2 \%$ in mierofossils. Consequently, nitrogen levels and $\mathrm{C} / \mathrm{N}$ ratios provide a useful tool for distinguishing recent biological contaminants from indigenous microfossils.

Cyanobacteria play a crucial role in nitrogen fixation on planet Earth. The nitrogen content of living cyanobacteria often amount to more than $10 \%$ by weight. ${ }^{\text {t3 }}$ A nitrogen deficiency immediately affects the amount of phycobiliproteins and consequently their photosynthetic light harvesting efficiency. The nitrogenase enzymes are extremely sensitive to oxygen and therefore in order to fix nitrogen an anaerobic environment must be provided. Cyanobacteria are oxygenic photoautotrophic microorganisms that are primarily aerobic microorganisms and therefore they must provide specialized cells to facilitate this process. The diazotrophic cyanobacteria (capable of using $\mathrm{N}_{2}$ as their sole source of nitrogen for growth) can be stibdivided into three groups:

Group 1: Heterocystous Cyanobacteria: Exchusively filamentous cyanobacteria that differentiate special cells (heterocysts) which have lost the capacity for oxygenic photosynthesis. Thick walled heterocysts form a diffusion barrier for gases and limit the entry of oxygen so that they can carry out diazotrophic growth under fully aerobic conditions. The heterocyst prevents oxygen from entering the cell where the nitrogen fixation is taking place. Heterocystous cyanobacteria include: Calothrix, Anaboena, Nodalaria, and Scytonema. The Orgueil meteorite contains filarnents interpreted as morphotypes of Calohrix, but the other Genera have yet been detected.

Group II: Anaerobic $N_{2}$ Fixing Non-Heterocystous Cyanobacteria: These are both flimentous and unicellular. They function by locating themselves in microbial mats in regimes that allow them to avoid oxygen and they may require sulfide to inhibit oxygenic photosynthesis. Examples include: Oscillatoria limnetica, Plectonema boryanum, and several species of Lymgbya and Synechococcus. Most of the filamentous forms found in Orgueil are consistent with morphotypes of species of Osctilatotia and PLectonema.

Group III: Aerobic $N_{2}$ Fixing Non-Heterocystous Cyanobacteria: These include common filamentous components of cyanobacterial mats such as: Microcoleus chthonoplastes, and various species of Lyngbya, Oscillatoria, Thichodesmium, and Gloeothece. The exact strategy is still not known but it may inclade temporal separation of the nitrogen fixation and oxygenic photosynthesis stages.

\subsection{Nitrogen in earbenaceoss meteorites and terrestrial fossils:}

Although Nitrogen is abundant in living organisms, it is severely depleted in meteorites. "During his initial investigations of Orgueil, Cloë $z^{1,2}$ reported the detection of an ammonium compound at approximately $0.1 \%$ (weight \%). He considered the ammonium to be present as a water soluble ammonitum and chlorine salt that he called "ammonium hydrochlorate. ${ }^{2}$ In 1963 , Mason ${ }^{45}$ concluded that the Orgueil anmonium salts were probably in the form 
of $\mathrm{NH}_{4} \mathrm{Cl}$ or $\left(\mathrm{NH}_{4}\right)_{2} \mathrm{SO}_{4}$. Moore ${ }^{46}$ reported finding $2,400 \mathrm{ppm}$ nitrogen $(0.24 \%$ atomic) in Orgueil and $2,900 \mathrm{ppm}$ in the Alais meteorite. Gibson et al., ${ }^{47}$ analyzed 27 carbonaceous meteorites and found that carbon-rich meteorites were also enriched in nitrogen. The broad variations in the nitrogen levels of individual samples show the heterogeneous distribution of nitrogen in Orgueil.

Nitrogen is also severely depleted in ancient fossils. It enters the geological cycle through the enzymatic fixation of atmospheric $\mathrm{N}_{2}$ and it is transformed into ammonium. Gallien et at, used Nuclear Reaction Analysis (NRA) to investigate the nitrogen and carbon content of biogenie and abiogenic minerals in Paleozoic shales and found the following atomic $\mathrm{CAN}$ ratios:
Abiotic Devonian hydrothermal feldspars:
Marine bacteria
$\mathrm{C} / \mathrm{N}=0.13-0.26$
Biogenic minerals
$\mathrm{C} / \mathrm{N}=2.9-14.3$
Proterozoic kerogens
$\mathrm{C} / \mathrm{N}=17-25$
Archaean kerogens
$\mathrm{C} N=104-167$
$\mathrm{C} / \mathrm{N}=200-500$

These published results are consistent with the data from the EDS investigations carried out at the NASAMSFC Astrobiology Laboratory on a wide variety of recognizable microfossils in carbonaceous meteorites, as well as fossils of trilobites, fish and prokaryotic filaments in terrestrial nocks as well as the data obtained from EDS studies of living and ancient biological materials. Table 2 provides the $\mathrm{CN}$, $\mathrm{C} / \mathrm{O}$ and $\mathrm{C} / \mathrm{S}$ values for number of representative examples. The Electron Energy-Loss Spectroscopy EELS or NRA systems ${ }^{42}$ are much more sensitive to the low-Z elements than the Energy Dispersive X-tay Spectroscopy (EDS) systems employed in the present investigation. Even under ideal conditions the EDS rarely detects the low-Z element Nitrogen at levels as below $0.2 \%$ $(2000 \mathrm{ppm})$. However, since these elements are detectable at levels above $5000 \mathrm{ppm}(\sim 0.5 \%)$ a value of $0.5 \%$ was used to estimate the lower limit for $\mathrm{C} / \mathrm{N}$ and $\mathrm{C} / \mathrm{S}$ ratios when Nitrogen or Sulfur values were returned as $0.00 \%$ by the Energy Dispersive X-tay Speetrometer software.

\subsection{Sulfur, Phosphorus, and Magnesium in carbonaccous meteorites and terrestrial fossils}

Sulfur is a major biogenie element that comprises a storage component for many bacteria. The strong covalent distlfide bond is cthcial to the folding, structure, and function of proteins. Sulfur ts a minot constituent in carbonaceous meteorites. The sulfur content is highest level $(5.9 \%)$ in the $\mathrm{CI}$ carbonaceous meteorites and the carbonates and sulfates in Cl and CM metoonites provides evidence for aqueous activity on the parent body. ${ }^{43}$ Although sulfur is critical for life, it ranely exceeds a percent in living organisms. However, the sulfur content of the Orgueil filaments is extremely high $(-10-50 \%$ in the filaments) but it is much lower in the Orgueil matrix. This point is dramatically illustrated in the $2 \mathrm{D} \mathrm{X}$-ray map of $\mathrm{Fig} 2 \mathrm{~b}$, where the filaments glow brightly in Sulfur against the meteorite rock matrix backgromd. The sulfur levels found in the flaments of the Orgueil meteorite are significantly higher than present in living cyanobacteria and other microbial extremophiles.

Phosphorus is a crucial component of the RuBisCo enzyme and it is essential for the nucleotide adenosine triphosphate (ATP) - the major energy currency of cells. However phosphorus is a minor component of the CI meterrites ${ }^{4,45}$ and is present at $\sim 0.08$ weight\% for the Orgueil meteorite. Phosphorous is rarely detected in the Orgueil filaments atd it is typically at very low levels $(<0.5 \%)$ in living cyanobacteria, bacteria, arehaea and diatoms.

Magnesium is a minor biogenic element in terms of the amonnt present in cells, but it is used in enzymes and plays a major role in photosynthesis as a component of chlorophyll. Magnesium is a major element in the CI meteorites, where it comprises $-9.6 \%$ by weight Much of the magnesiutn is in water-soluble hydrated magnesium sulfate (in different stages of hydration) and as hydrafed $\mathrm{Mg}$ layer-latice silicates (serpentine or chlorite). ${ }^{44}$

\section{RESULTS}

\subsection{Images and EDS elemental abundanees of flaments in the Murchisen CM2 Meteorite}

During the past decade, the ElectroSean Environmental Scanning Electron Microscope (ESEM); the FEI Quanta 600 FEG and the Hitachi S-4100 Field Emission Scanning Electron Microseopes (FESEM) were used at the NASA Marshall Space Flight Center to produce high resolution images and Energy Dispersive X-ray Spectroscopy (EDS) andyses and 2-D X-ray maps of elemental compositions of embedded microfossils in ancient rocks and carbonaceous meteorites. Comparative studies with the same instrumentation was carried out on a wide variety of 
megafossils (Trilobites, Fish, etc.) as well as known fossils of Proterozoic and Archaean cyanobacteria and associated filamentous prokaryotes and environmental samples and pure cultures of living cyanobacteria and axenic cultures of type strains of novel genera and species of bacteria and archaea. Freshly fractured interior surfaces of many of the CI and $\mathrm{CM}$ carbonaceous meteorites have been found to contain many complex and embedded filaments consistent in size, shape, and morphology with known species of cyanobacteria and associated filamentous trichomic prokaryotes.

An ElectroScan ESEM image at $15 \mathrm{keV}$ of a filament in the Murchison CM2 carbonaceous meteorite is shown in Figure 1.a. This image is interpreted as the mineralized remains of an emergent hormogonium from a morphotype of cyanobacteria (cf. Nostoc sp.). The EDS spectrum (Fig, 1.b) at spot X shows C 41.7\%; O 16.8\%; S $6.1 \%$ and $\mathrm{N} 0.0 \%$ (taken as $\mathrm{N}<0.5 \%$ ) gives elemental abundance ratios: $\mathrm{C} / \mathrm{O}=2.5 ; \mathrm{C} / \mathrm{N}>82 ; \mathrm{C} / \mathrm{S}=6.8$. Detectable levels of Iron and Nickel are observed. The suite of elements is consistent with that observed in the meteorite matrix at point Y providing a clear indication that the filament belongs to the meteorite and it is not a recent biological contaminant.
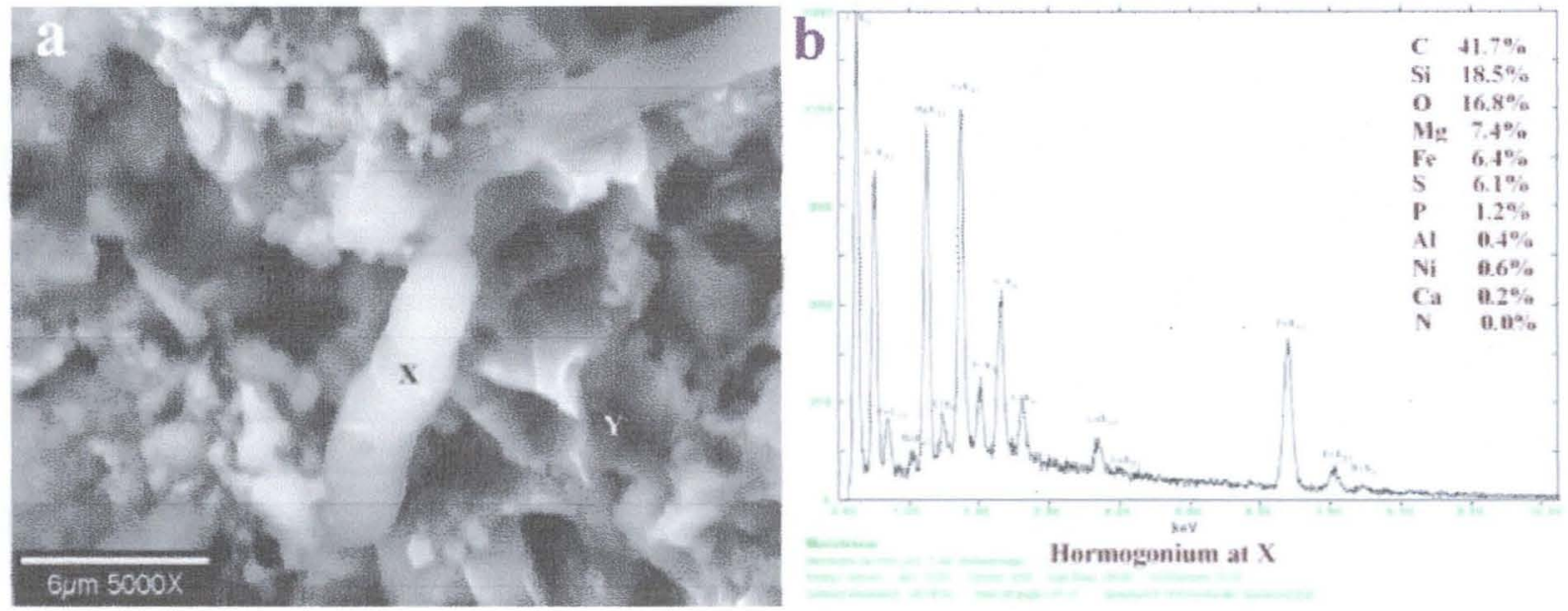

Figure1a. Filament with crosswall constrictions in the Murchison CM2 meteorite interpreted as emergent hormogonium of species of Nostocacean cyanobacteria. b. EDS spectrum at $\mathbf{X}$ shows elemental composition of filament similar to Murchison matrix but enriched in Carbon ( $\mathrm{C}=42 \% ; \mathrm{O}=16.8 \% ; \mathrm{S}=6 \% ; \mathrm{Ni}=0.6 \% ; \mathrm{N}<0.5 \% ; \mathrm{C} / \mathrm{N}=82 ; \mathrm{C} / \mathrm{O}=2.5 ; \mathrm{C} / \mathrm{S}=6.8$ ).

\subsection{Images and EDS elemental abundances of filaments in the Orgueil CI1 Meteorite}

The vast majority of the embedded filaments in the Orgueil $\mathrm{CIl}$ carbonaceous meteorite have electron transparent carbon-rich sheaths enveloping a permineralized interior rich in magnesium and sulfur. This is interpreted as the result a fluid infused with a magnesium sulfate solution infilling the hollow carbonized sheath after death of the filamentous prokaryote. It has been known since shortly after the meteorite fell in 1864 that the Orgueil meteorite is a microregolith breccia that disintegrates immediately when it comes in contact with liquid water.$^{1-3}$ Consquently, it is suggested that the infilling of the interior of these carbon-rich envelopes must have occurred on the parent body prior to entry into the Earth's atmosphere. Some of the envelopes of the Orgueil filaments and sheath-like electrontransparent envelopes have over $80 \%$ (atomic) carbon. All of the filaments found have extremely high levels of magnesium and sulfur. This result is consistent with a magnesium sulfate rich fluis infilling hollow carbonaceous sheaths of cyanobacteria or filamentous sulfiur bacteria after death. This would require a flow of liquid water and since the Orgueil CIl meteorite is destroyed by liquid water, this observation is interpreted as providing strong evidence that the permineralization of the filaments took place on the parent body prior to entry of the meteorite into the Earth's atmosphere. Figure 2.a. is a Hitachi Field Emission Scanning Electron Microscope (FESEM) image of a small spiral filament in Orgueil with size and morphology similar to known representatives of the modem helical cyanobacterium Spirulina sp. The EDS spectral data from spot X is shown in Fig, 2.b.

Figure 3a. is a a 1000X FESEM image of a very small $(\sim 120 \mu \mathrm{m})$ fragment of the Orgueil meteorite with Fig. 3.b. a 2D X-ray elemental map. This small region is densely populated with many different types of embedded filaments and electron transparent sheaths. Several of the filaments have complex morphological features that are well known in modern cyanobacteria and other trichomic prokaryotes. The major filaments and sheaths are clearly seen as bright features in the $\mathrm{C}, \mathrm{O}, \mathrm{Mg}$ and $\mathrm{S}$ maps and they appear as dark features in $\mathrm{Si}, \mathrm{Fe}$, and $\mathrm{Ni}$ maps due to the 
relatively higher content of these elements in the underlying Orgueil meteorite rock matrix. Filament 1 can be clearly discerned in the Nitrogen map and the wrinkled, electron transparent, empty sheath 7 has a relatively high $(47 \%)$ content of Carbon content. It is one of the only filaments ever found in the Orgueil meteorite with detectable levels of both Nitrogen (1\%) and Phosphorus (0.8\%). The irregular longitudinal striations of filaments $\mathbf{1}$ and $\mathbf{2}$ suggest these are multiseriate filaments in which multiple parallel oriented trichomes are enclosed within a common homogeneous sheath. Both of these filaments appear to be attached to and physically embedded in the rock or clay substratum of the Orgueil meteorite matrix and thus they may represent epilithic or epipelic forms.

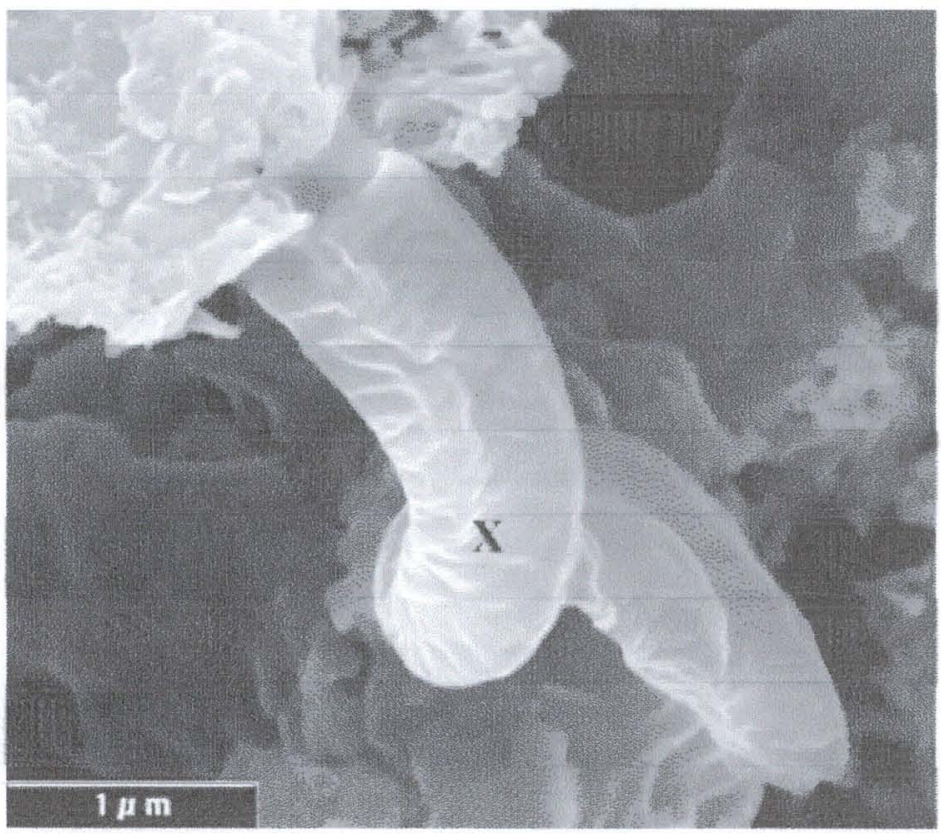

a.

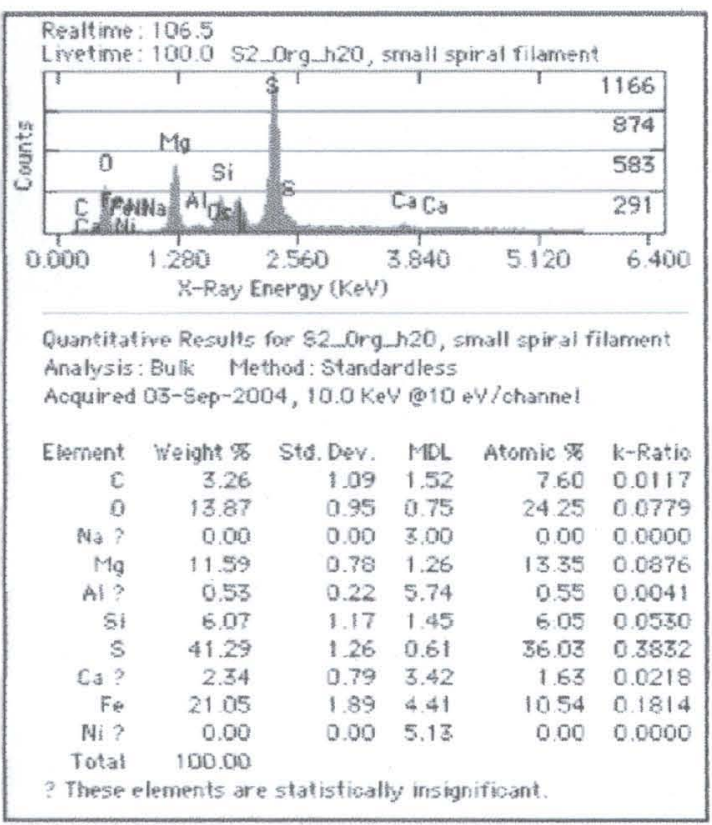

b.

Figure 2.a. Morphotypes of Spirulina sp.in the Orgueil meteorite with b. EDS spectrum showing elemental abundances of Magnesium sulfate permineralized filament at spot X. (C 7.6\%; N $<0.5 \% ; \mathrm{O} 24 \% ; \mathrm{S} 26 \% ; \mathrm{C} / \mathrm{N}>15 ; \mathrm{C} / \mathrm{S}=0.3 ; \mathrm{C} / \mathrm{O}=0.3$ )
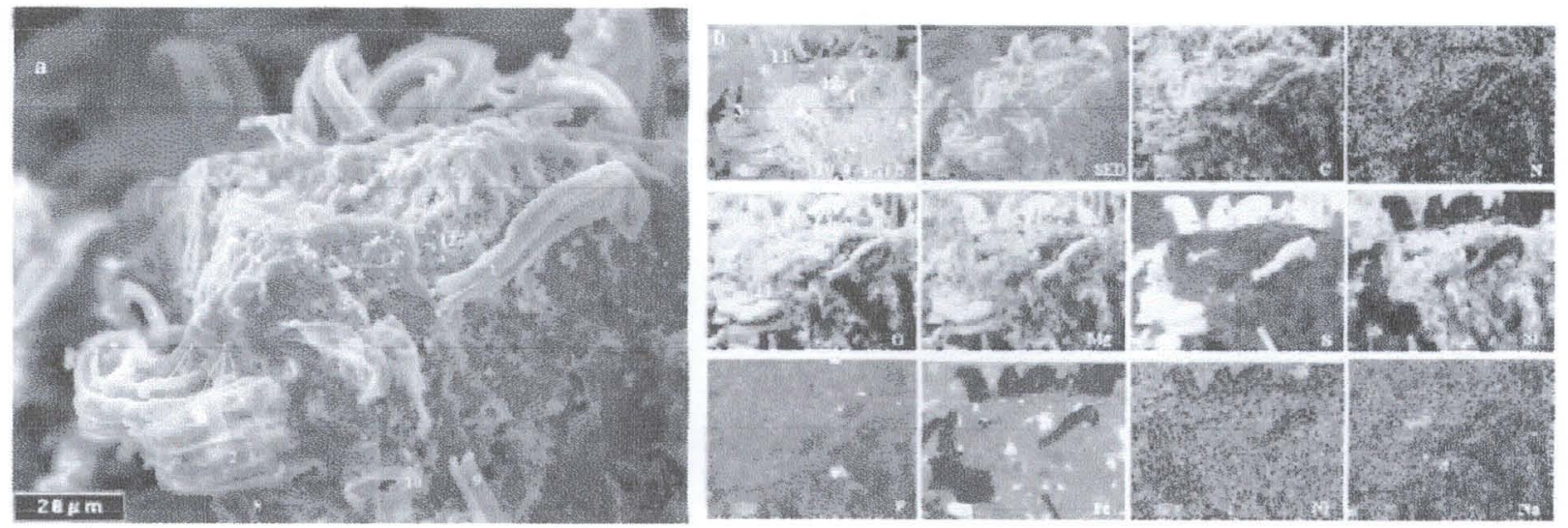

Figure 3. FESEM SED and BSED images and 2-D Elemental X-Ray Maps of Orgueil fragment with many different types of embedded filaments and empty carbonaceous sheaths. EDS spot data for numbered spots given in Table 2.

The end of Filament 1 widens slightly $(\sim 10 \mu \mathrm{m})$ where it joins the rock matrix and it appears to contain four trichomes with diameters $\sim 2.5 \mu \mathrm{m}$ /trichome. The larger filament $2(\sim 20 \mu \mathrm{m}$ dia. $)$ has longitudinal striations suggestive of $\sim 5$ trichomes with diameters $\sim 4 \mu \mathrm{m} /$ trichome. Faint cross wall constrictions are visible in Filament 2 suggesting the internal cells are $\sim 4 \mu \mathrm{m}$ in length and hence roughly isodiametric. The inferred configuration of filament $\mathbf{2}$ is that it consists of an ensheathed trichome bundle of parallel trichomes composed of isodiametric cells of 
$4 \mu \mathrm{m}$ diameter as is well known in modern morphotypes of undifferentiated filamentous Oscilliatorialean cyanobacteria of the genus Microcoleus Desmazières ex Gomont) (See Castenholz, Rippka \& Herdman ${ }^{49}$ ). Reproduction within this order occurs by trichome fragmentation and the production of undifferentiated short trichome segments (known as hormogonia) by binary fission of the cells in one plane at right angles to the long axis of the trichomes. The small multiseriate filament 1 is interpreted as representing a morphotype of the genus Trichocoleus Anagnostidis ${ }^{50}$, which was separated from the genus Microcoleus on the basis of cell size and morphology. Trichomes of species of the genus Trichocoleus are typically of $0.5 \mu \mathrm{m}-2.5 \mu \mathrm{m}$ diameter. EDS spot spectral data on the meteorite rock matrix and several of the numbered filaments and sheaths are given in TABLE 2.

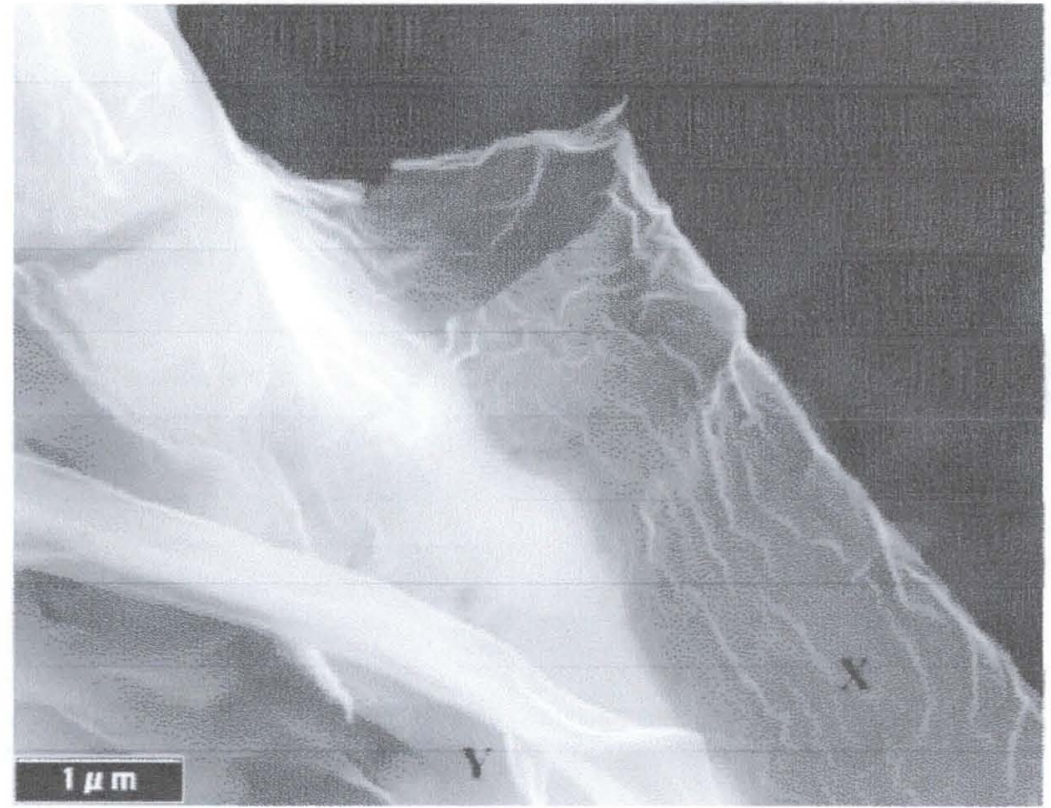

a.

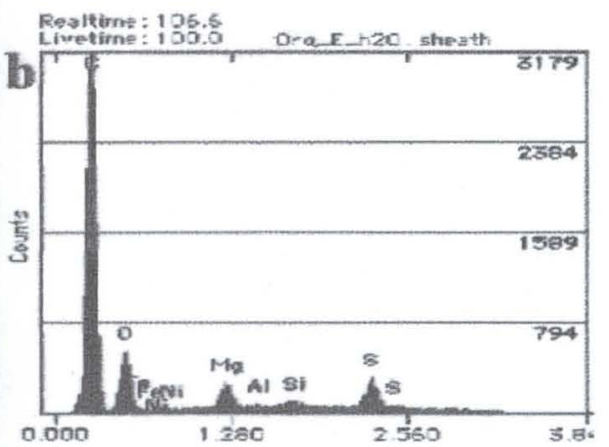

Quantitative Results for Crg_E_h20, sheath Analysis: Bulk Methad: Standard less Acquired 25-Aug-2004, $50 \mathrm{KeV}$ o 10 -4/ohamel Element woight se Sed. Der. MBL Atomic $\$$

\begin{tabular}{|c|c|c|c|c|}
\hline 4 & tro igt & Se & WL & mis is \\
\hline c & 70.63 & 1.95 & $0.1 \leqslant$ & 81.98 \\
\hline 0 & 10.59 & 0.71 & 0.48 & 923 \\
\hline Mg & 3.97 & 1.02 & 1.56 & \\
\hline AI? & 0.00 & 0.00 & 2.10 & 00 \\
\hline Si? & 1.16 & 0.44 & 328 & c \\
\hline s & 1365 & 0.94 & 139 & \\
\hline Fe? & 0.00 & 0.00 & 2.85 & \\
\hline$\omega i s$ & 0.00 & 0.00 & 2.43 & \\
\hline Total & 100.00 & & & \\
\hline
\end{tabular}

b.

Figure 4.a Orgueil filament with wrinkled de-laminated carbon-rich sheath. b. EDS spectra at spot X on sheath.

Figure 4.a. is a Hitachi FESEM image at $6000 \mathrm{X}$ of a complex, curved and polarized filament in Orgueil. The basal region of this branched filament is $\sim 8 \mu \mathrm{m}$ diameter and primary trichome tapers to $3 \mu \mathrm{m}$ diameter at the apex. The terminal end of the filament is covered with an electron transparent mucilaginous sheath that encloses a $0.4 \mu \mathrm{m}$ diameter terminal hair. The filament exhibits both " $\mathrm{T}$ " and " $\mathrm{Y}$ " branching configurations and the secondary trichomes are much narrower than the primary trichome. The secondary trichome at the lower center of the image forms a " $Y$ " branch and then terminates in rounded empty sheaths. The $\mathrm{Y}$ branching and other features are suggestive of cyanobacteria of the Order Stigonematales, Geitler. ${ }^{51}$ Some modern representatives of the genus Fischerella have branches that are much narrower than the main filament. This Order includes species that grow in thermal springs such as Mastidocladopsis lyengar et Desikachary. ${ }^{52}$ The Orgueil filament has a large nodule near the base that may represent lateral heterocysts, such as is sometimes seen in the genus Mastidocladopsis. This genus has not been extensively studied and only two tropical freshwater species (often found attached to stony substrates) have been described. The sheath of the Orgueil filament is wrinkled and laminated, which may be the result of the conditions in which fossilization took place. It should be also noted that the modern genus Hapalosiphon also has species with tapered and curved main filaments $\sim 8 \mu \mathrm{m}$ (e.g., Hapalosiphon welwitschii 5-7.5 $\mu \mathrm{m}$ ). Hapalosiphon hansgirgi has 6-8 $\mu \mathrm{m}$ diameter main filaments narrowing to about $5 \mu \mathrm{m}$ at the apex but none have been reported with such narrow branches. The EDS spectrum of the sheath $(4 \mathrm{aX})$ is exceptionally enriched in carbon $(82 \% \mathrm{C})$ and has a $\mathrm{C} / \mathrm{O}$ ratio of 8.9. This is consistent with coal or kerogen but dramatically different from the samples of living, recently ancient (Pleistocene and Holocene) biological material. The EDS spectra for the filament interior (4aY in Table 2) shows it is permineralized with magnesium sulfate and has nitrogen content below the detection limit. 


\subsection{Images and EDS elemental abundances of Archaean filamentous prokaryetes}

During this study we also evaluated the $\mathrm{C} / \mathrm{N}, \mathrm{C} / \mathrm{S}$ and $\mathrm{C} / \mathrm{O}$ ratios from fossil filamentous trichomic prokaryotes and cyanobacteria from the Upper Archean (lopian) rocks of Northern Karelia. Specimens from the Upper Archaean (lopian) deposits of Northern Karelia were collected by V.A. Matrenichev and N.A. Alfimova from the Institute of Geology and Geochronology of Precambrian of the Russian Academy of Sciences and provided by Prof. A. Yu. Rozanov, M. M. Astafieva, and Y.E. Malakhovskaya of Paleontological Institute (RAS). The samples were collected from the Northern part of Khisovaar structure (Parandovsk-Tikshosersk greenstone belt) which consists of thick complicated complex of volcanogenic-sedimentary rocks. The upper part of sedimentary complex was found to have isotopic age of $2706 \pm 7$ million years and the lower portion $2803 \pm 35$ million years. ${ }^{53,54}$

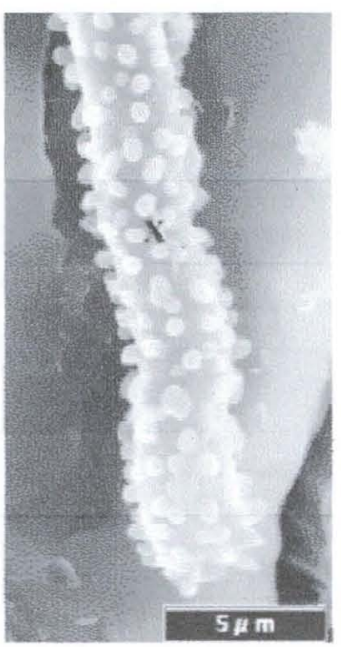

a.

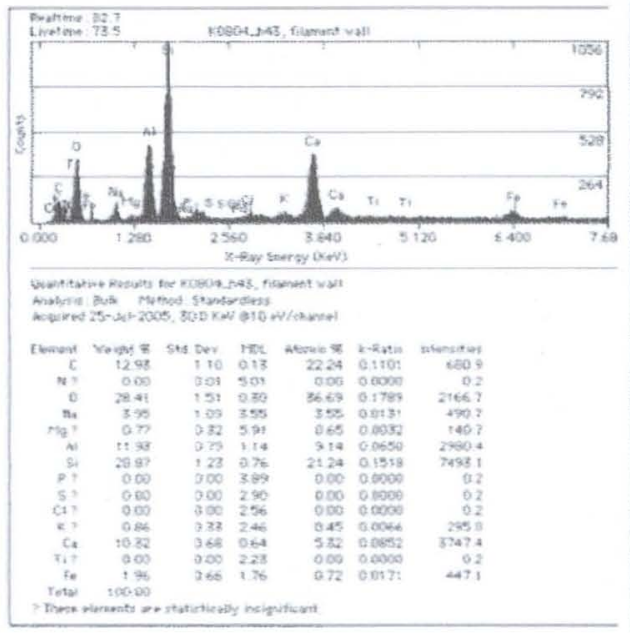

b.

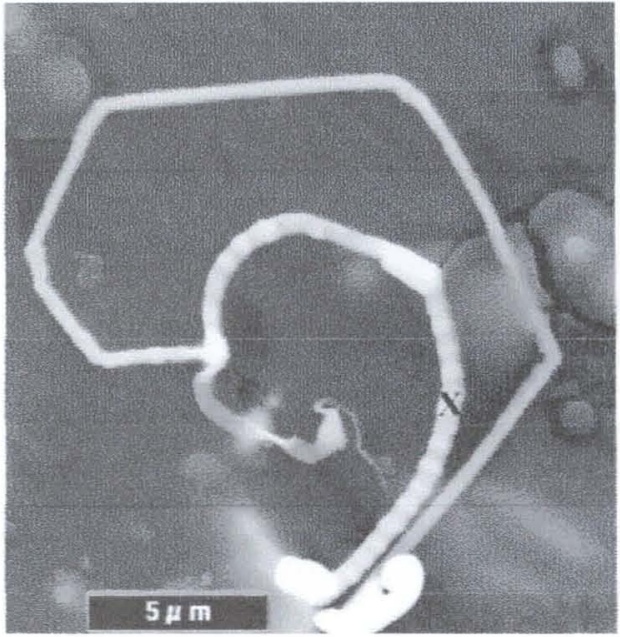

c.

Figure 5.a Mineralized filaments from carbonaceous shales of the Upper Archaean (lopian) rocks ( $2.7 \mathrm{Ga})$ of Northern Karelia. a. Morphotype of oscillatorialean cyanobacterua with external nodules on isodiametric filament with b. EDS elemental composition . c. Unusual segmented filament of unknown affinity in Karelian rock. (EDS spectral data for spot X provided in Table 2 as 5 cX.)

\subsection{Images and EDS abundances of Cambrian and Ordovician trilobites, Devonian Mites, and Eocene fish}

Energy Dispersive X-ray Spectroscopy analyses were also carried out to determine elemental compositions of well known terrestrial fossils such as Cambrian and Ordovician trilobites, Devonian mites and cyanobacterial filaments and Eocene fish. Figure 6.a is a visible light image of Brachyaspidion microp. ${ }^{55}$ This is small wellpreserved Middle-Cambrian ( $\sim 500 \mathrm{Ma})$ trilobite of Order Ptychopariida was collected by the author in the Wheeler Springs Formation, House Range, Millard County, Utah. The Wheeler Shale mudstones are comprised exclusively of a fine-grained mixed carbonate mud and clay that accumulated below the influence of storm waves. The Wheeler Shale contains a very rich and diverse biota, including an abundance of benthic trilobites (e.g., Asaphiscus wheeleri and Bollaspidella wellsvillensis and many soft-bodied members of the Burgess Shale fauna. The Wheeler Formation accumulated in a deep, localized, fault bounded trough known as the House Range embayment on a broad sulfur-rich, carbonate platform. $^{57}$ The presence of Burgess fauna and Burgess Shale type preservation indicates an anoxic deposition in the absence of bioturbation. These are ideal conditions for extensive production of benthic, sulfuroxidizing anaerobic chemolithoautotrophs, such as Beggiotoa and Thioploca.

These microbial communities could have provided a rich food source for Cambrian metazoans, such as the trilobites of the Wheeler Shale. Figure 6.b is a visible light image of the common Middle Cambrian Trilobite Peronopsis interstricta (Order Agnostida, Family Peronopsidea) from the Wheeler Formation, House Range, Utah. This small agnostid trilobite had no eyes and only two thoracic segments. Figure 6.c is a well-preserved Ordovician trilobite $(445 \mathrm{ma})$ Reacalymene limba from the Ashgill formation of North Wales. This inflated specimen is $27 \mathrm{~mm}$ long and has a semicircular cephalon and small, holochroal eyes.

A low magnification (900X) ESEM image of a fragment of an Orabatid mite with well preserved trichobotrias from Devonian graphite of the Botogol deposit of East Sayan (South Siberia) ${ }^{58,59}$ is shown in Fig. 6.d. It is now accepted thate these raphites were formed by the conversion of highly carbonic sedimentary carbonate rocks 
Fig. 6.e. is a $4000 \mathrm{X}$ ESEM image of a filament with size and morphology similar to known trichomic filamentous cyanobacteria of the Order Oscillatoriace. The spots at which the EDS data shown (Table 2) were obtained are marked on the filament. Fig.6.f is a visible light image of the small Eocene ( 50 Mya) schooling fish (Knightia sp.) commonly found in the laminated sandstone of the Green River Formation of Kemmerer, Wyoming. The EDS spectral data for the marked spots on the trilobites and the spot $\mathrm{C}$ on the mineralized bone just beneath the eye socket of the Eocene fish are given in Table 2.

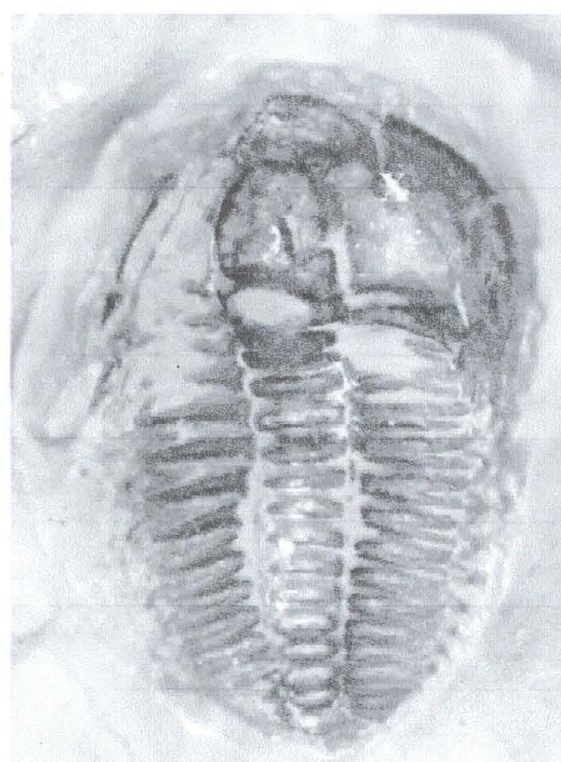

a.

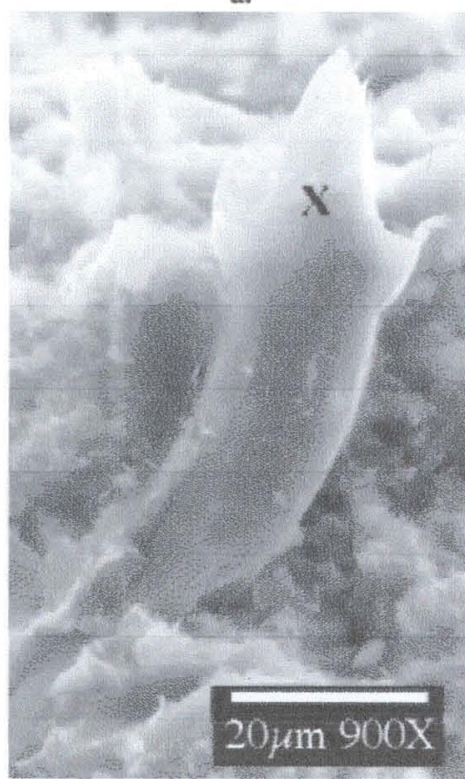

d.

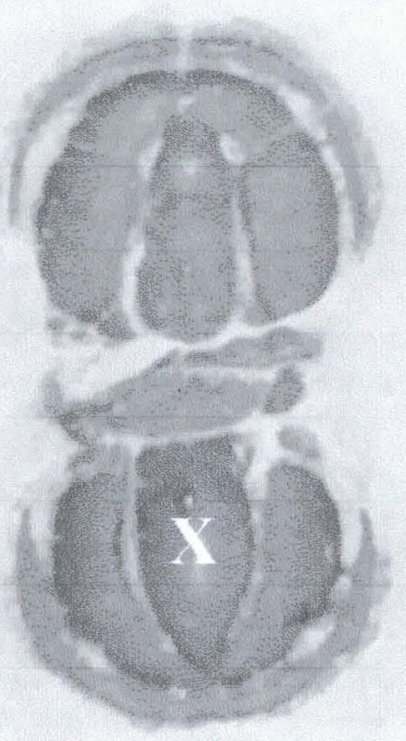

b.

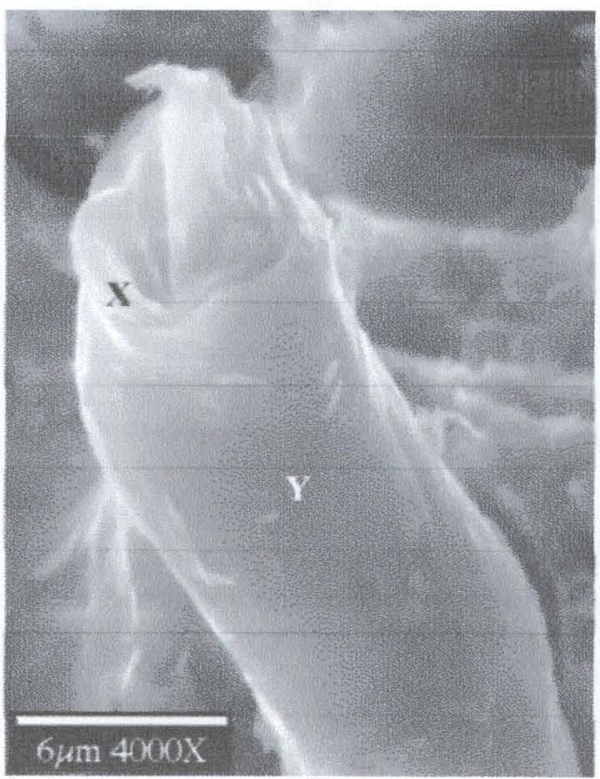

e.

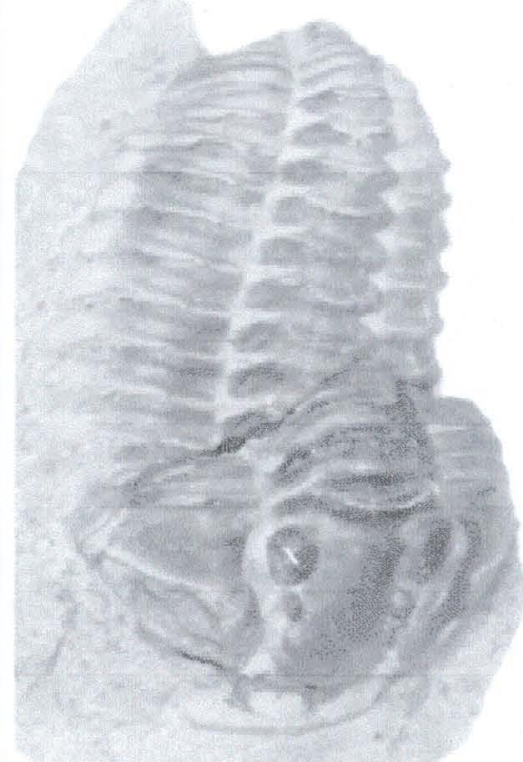

c.

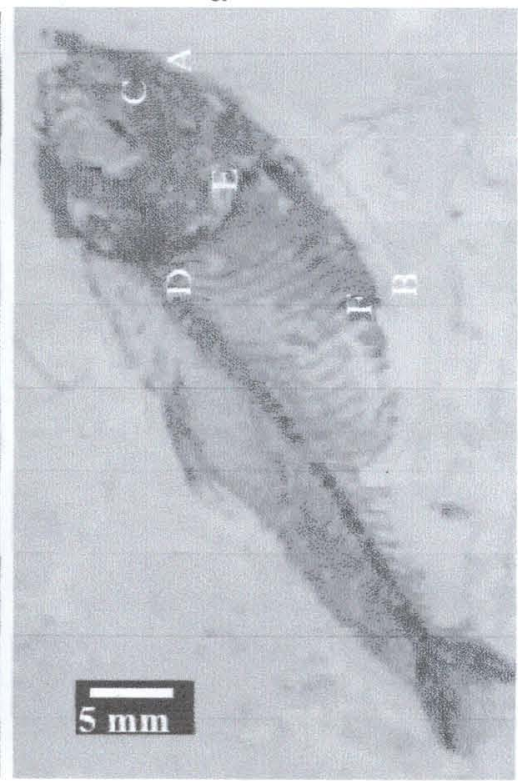

f.

Figure 6. Middle Cambrian ( $\sim 500 \mathrm{Ma})$ trilobites a. Brachyaspidion microps and b. Peronopsis interstricta from the Wheeler formation, near Swazey, Peak, House Range, Millard County, Utah c. Ordovician trilobite Reacalymene limba from Ashgill fm. (449-443 Ma) of North Wales. d. Image of Devonian Orabatid mite fragment and e. trichomic filament in the graphites from Botogol, South Siberia. f. Eocene ( 50 Mya) schooling fish (Knightia sp.) with EDS spectra in Table 2 from Spot $\mathrm{C}$ of the bone just beneath the eye. 


\subsection{Images and EDS elemental abundances of Pleistocene filaments from Vostok Ice Cores}

The Central Antarctic Glacier at Vostok is $\sim 3.7 \mathrm{~km}$ thick ice sheet that overlays the 500 meter deep Lake Vostok. Sabit Abyzov et al. ${ }^{60-62}$ have pioneered the study of viable microorganisms from the deep ice of the Central Antarctic ice sheet above Lake Vostok. They have shown that microorganisms can remain alive in a state of deep anabiosis for many thousands of years. Collaborative in-situ studies of Vostok ice and thawed ice cores precipitated on membrane filters were carried out at MSFC. These studies primarily used the Electroscan Environmental Scanning Electron Microscope (ESEM) to image ice fragments as they were allowed to melt in the instrument chamber. This made it possible to absolutely establish that the forms that were observed to emerge from the interior of the Vostok ice samples were indigenous and could not be interpreted as recent biological contaminants. Abundant microorganisms were found in all layers (102 M to $3611 \mathrm{M}$ ) of the ice sheet examined. Great variations in the composition, density and distribution of particulates and recognizable microorganisms were observed from one layer to another.
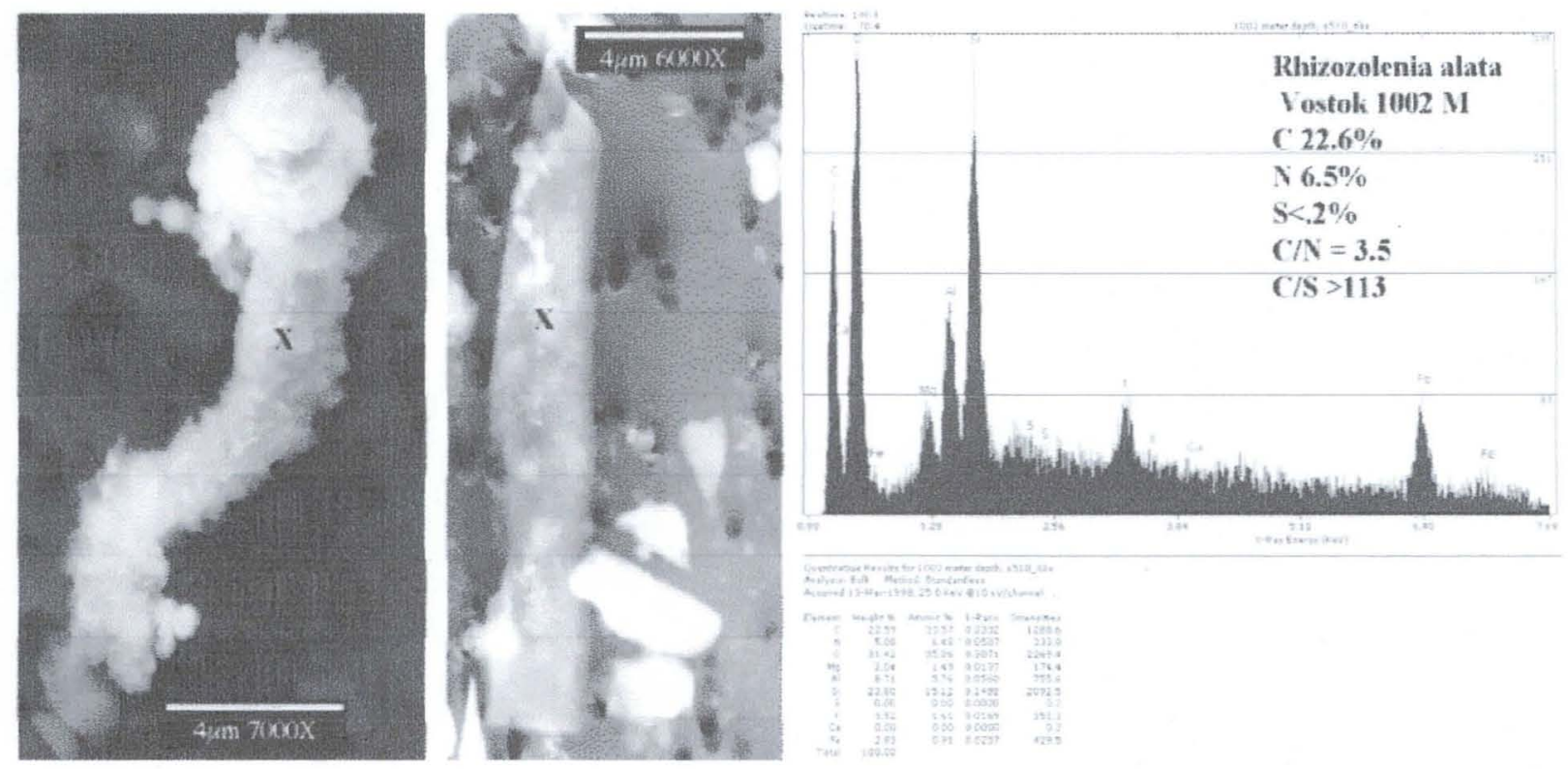

Figure 7. ESEM images of Pleistocene microbiota from Vostok ice cores: a. trichomic cyanobacterium from 1249M depth; b. diatom (cf. Rhizosolenia alata var. gracillima) from $1002 \mathrm{M}$ deep ice layer with c. EDS spectrum at spot X.

Figure 7.a.is an Electroscan ESEM images of a helical coiled cryopreserved filament from the $1249 \mathrm{M}$ layer $(\sim 80,000 \mathrm{yrs})$ at Vostok. This filament has an emergent trichomic structure interpreted as a moprphotype of a filamentous cyanobacteria of the Order Oscillatoriace. Figure 7.b. is an ESEM image of a well-preserved diatom from 1002 meters depth (age $70,000 \mathrm{yrs}$ ). This diatom has been identified as Rhizosolenia alata var. gracillima (Cleve) Gran, which is one of the smaller representatives of the family Rhizosoleniaca. Some of the Rhizosolenia are gigantic. Rhizosolenia. styliformis has been reported with valve diameter up to $100 \mu \mathrm{m}$ and lengths exceeding 1500 $\mu \mathrm{m}$. The detection of this $R$. alata in the Vostok ice is interesting, since the family Rhizosoleniaceae is a marine planktonic diatom with no known freshwater forms. ${ }^{63}$ The EDS spectrum in Fig. 7.e. shows that the nitrogen content of this $\sim 80,000$ year old diatom from the Vostok ice core is similar to that of modern living diatoms.

\subsection{Images and EDS abundances of Hair/Tissue of Pleistocene Mammoth and Pre-dynastic Egyptian Mummy}

The FEI Quanta FEG Scanning Electron Microscope was used to obtain high resolution images and conduct EDS Elemental analyses of $\sim 15,000$ year old samples of Wooly Mammoth guard hair, undercoat hair and tissue. of Mammuthus primigenius, Blumenbach, 1799. These samples were collected by the author in 1999 during the International Beringia Expedition to the Kolyma Lowlands of Northeastern Siberia. In 1977, an exceptionally wellpreserved 40,000 year old frozen carcass of the baby Woolly Mammoth Dima was recovered near Magadan, Siberia from the permafrost near a tributary of the Kolyma river. ${ }^{64}$ Figure 8.a. is an image of a $\sim 200 \mu \mathrm{m}$ diameter guard hair. 
The square spot on this image is the result of beam damage to the hair by exposure to the $10 \mathrm{KeV}$ electron beam as the EDS data for this area shown in Fig. 8.b. were obtained. Figure 8.c. is an image of a small fragment of Mammoth tissue with several undercoat hairs still attached. The $\mathbf{X}$ is linked to the dark square produced by beam damage when the EDS data was taken on the mammoth tissue sample and the 5000 year old hair Fig. 8d. from the pre-dynastic Egyptian mummy. All of these ancient hair and tissue samples show strong Nitrogen peaks with $\mathrm{C} / \mathrm{N}$ and $\mathrm{C} / \mathrm{S}$ ratios similar to living biological materials. Beam damage is the result of heating breaking down the proteins, polysaccharides and other organics. It is very frequently observed when studying modern, Holocene and Pleistocene biological materials. Beam damage is only rarely seen during investigations of the filamentous microfossils found in the carbonaceous meteorites or in the mineralized microfossils and macrofossils found in Archaean, Proterozoic, and Phanerozoic (except Pleistocene and Holocene) rocks on Earth.

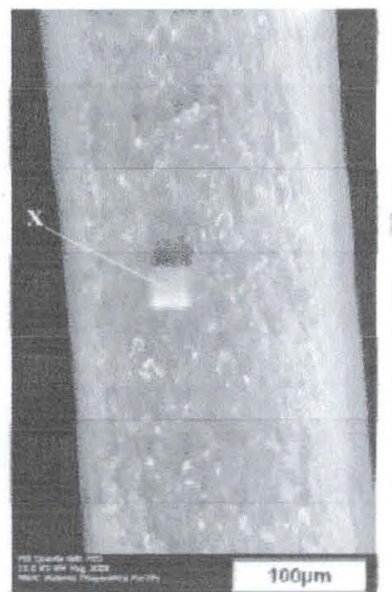

a.

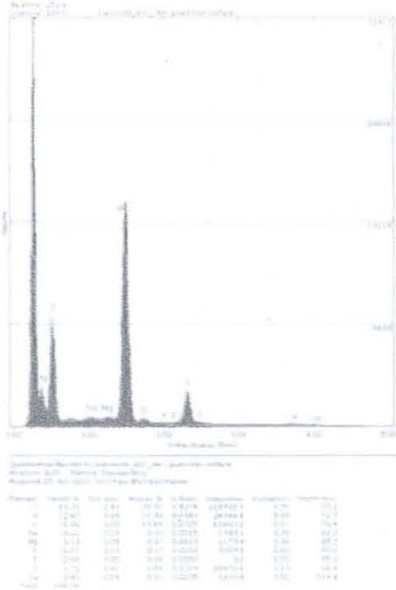

b.

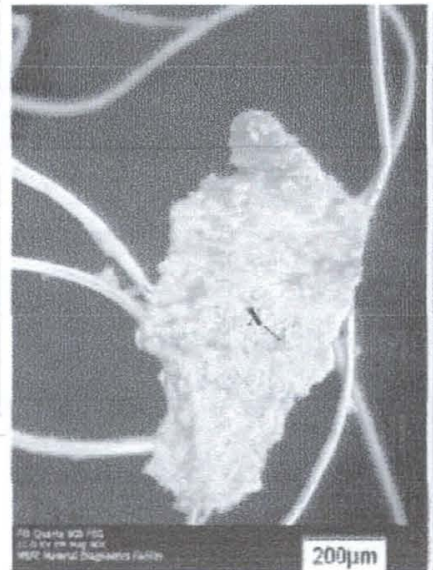

c.

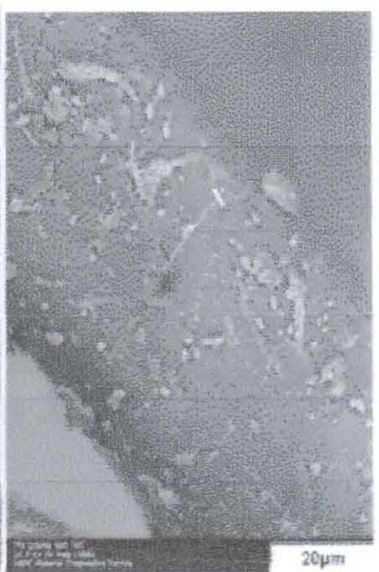

d.

Figure 8.a Mamuthus primigenius guard hair with b. EDS spectra at spot X and c. Mammoth tissue and undercoat hairs and d. FEI Backscattered electron detector image of pre-dynastic Egyptian mummy hair ( 5,000 Yrs.) showing beam damage at spot X where EDS spectral data shows strong Nitrogen peak ( $\mathrm{C} 64.3 \% ; \mathrm{N} 10.7 \% ; \mathrm{O} 19.6 \% ; \mathrm{S} 1.8 \% ; \mathrm{P}<.5 \% ; \mathrm{C} / \mathrm{N}=6 ; \mathrm{C} / \mathrm{S}=52 ; \mathrm{C} / \mathrm{O}=3.3$ ).

\subsection{Images and EDS elemental abundances of modern diatoms, bacteria and cyanobacteria}

The investigation also included determination of the ratio of biogenic elements in diatoms preserved for almost over 150 years on Herbarium sheets at the Henri Van Heurck Museum in Antwerp, Belgium as well as well as living cyanobacteria and bacteria (Fig. 9). The sample in Fig. 9.a. was collected by Hoffman Bang in 1816 and designated Bangia quadripunctata with an epiphytic filament attached to the diatoms. The EDS data for the filament at spots X and $Y$ and the diatoms at spot $Z$ are given in Table 2. The 500X FEI Quanta 600 FEG scanning electron microscope image of the type series of the diatom is shown in Fig. 9.b. These small naviculoid diatoms were collected by Lenormand in France in 1834 and mounted on an herbarium sheet and subsequently described by Kutzing ${ }^{65}$ as Schizonema lenormandi Kutzing, 1849. These diatoms were observed by the author to emerge from broken ends of their gelatinous sheaths and begin swimming after sterile distilled water was added to a well slide containing a small fragment of the filaments. ${ }^{66,67}$ Figure 9.e and $\mathbf{d}$. are Hitachi FESEM images of the living cyanobacteria Lyngbya subtilis and d. a collapsed filament of Oscillatoria lud,grown in pure culture at the NASA/NSSTC Astrobiology Laboratory. Figure 9.e. is a FESEM image of a living sample of axenic culture of the type strain Spirochaeta Americana, Hoover 2002 that was isolated from the sulfur rich black mud sediments of Mono Lake in Califormia. The EDS spectral data (Fig, 9.e) at spot X on a clump of the tiny helical coiled filaments shows a clearly delineated Nitrogen peak ( $\mathrm{N}=10.7 \%$, atomic) with $\mathrm{C}=62.3 \% ; \mathrm{O}=20.8 \%$ and $\mathrm{S}=0.4 \%$ $(\mathrm{C} / \mathrm{N}=5.8 ; \mathrm{C} / \mathrm{O}=2.7 ; \mathrm{C} / \mathrm{S}=156$. Figure 9.f. is a FESEM image of a living sample of axenic culture of type strain of microbial extremophiles ${ }^{68}$ Spirochaeta Americana, Hoover 2003 and the EDS spectra showing a clearly delineated Nitrogen peak is in Fig. 9g. The EDS data for the other samples are provided in Table 2

The EDS spectral data shown in Table 2 establish that the diatoms and filaments, which have been stored in dry condition since 1834, have Nitrogen levels and $\mathrm{C} / \mathrm{N}$ ratios are consistent with living microorganisms. These measurements on mammoth and mummy hair and tissue and diatoms and their associated gelatinous envelopes preserved dry on herbarium sheets for over a century and a half provide solid data indicating that the loss of nitrogen from biological samples occurs over geological rather than historical time scales. Consequently the absence of 
nitrogen in the filamentous microstructures found in freshly fractured interior surfaces of the carbonaceous meteorites indicates they should be interpreted are indigenous remains rather than recent microbial contaminants.

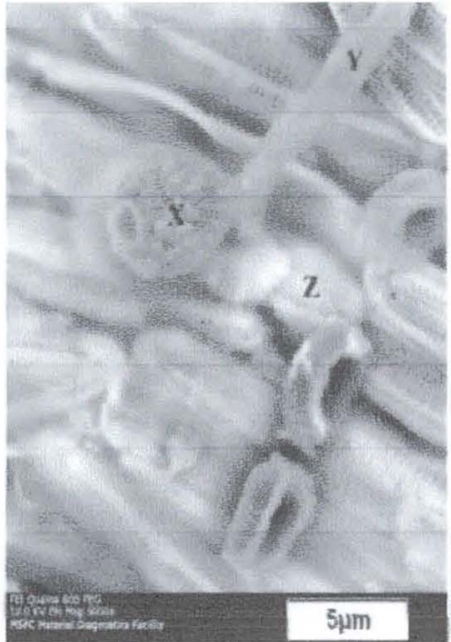

a.

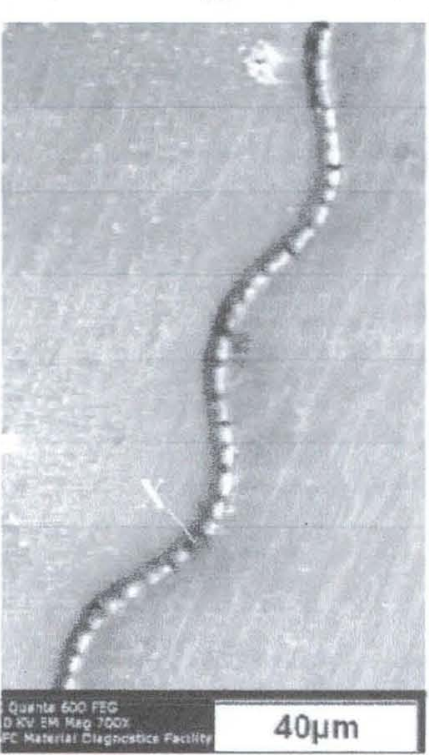

e.

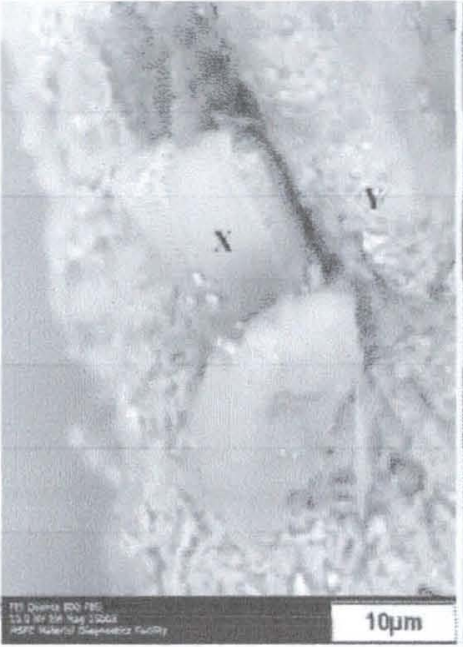

b.

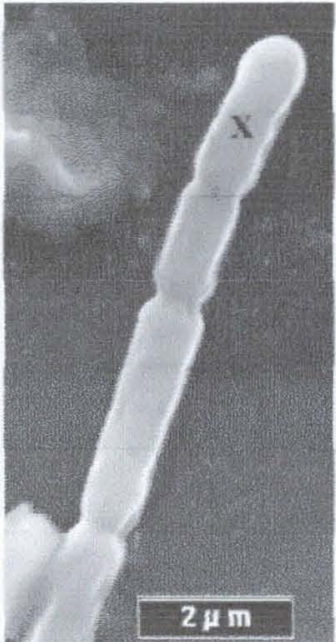

c.

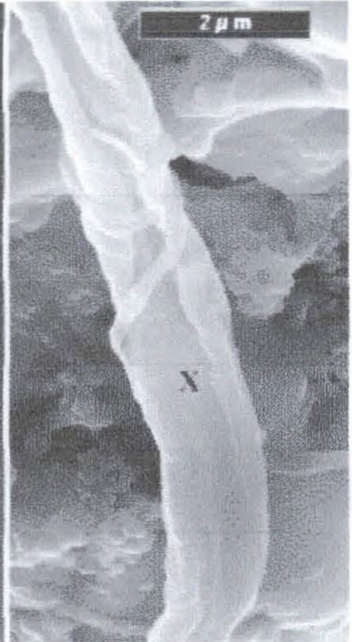

d.

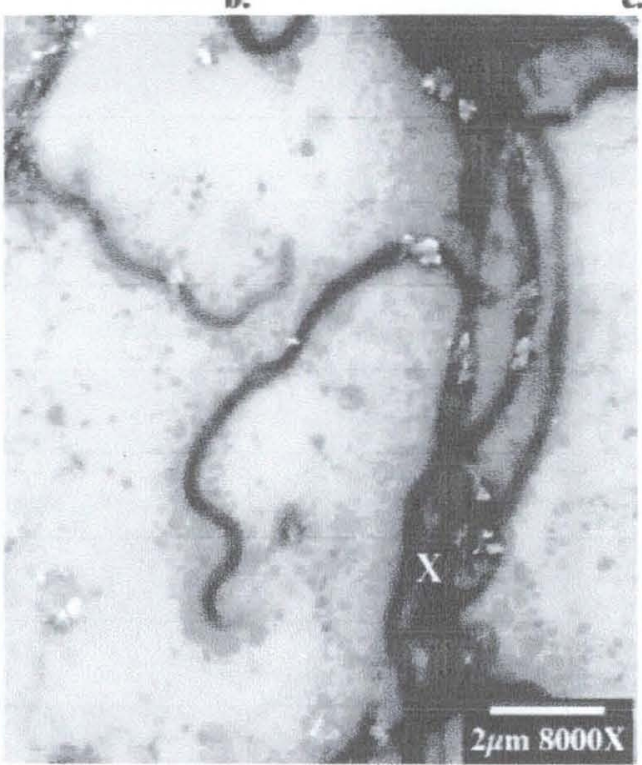

f.

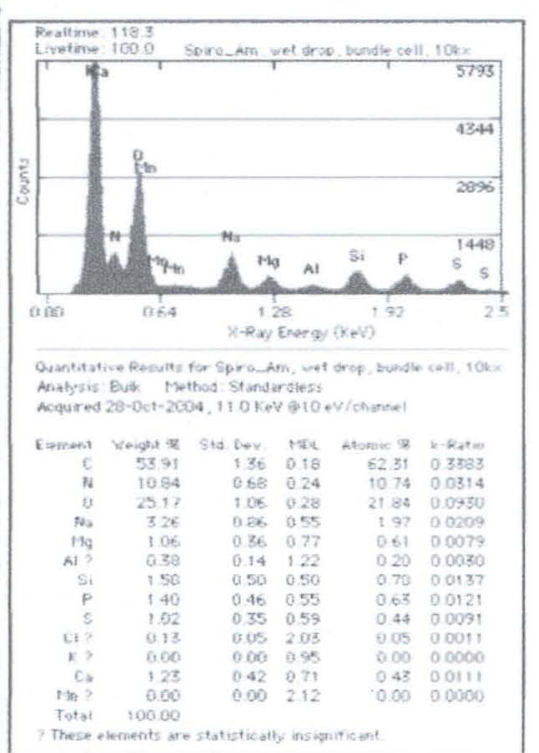

g.

Figure 9. Dried herbarium samples from 1816 of epiphytic filamentous forms on the diatom a. Bangia quadripunctata and b. the diatom Schizonema lenormandi Kutzing, 1849 marked where EDS data were obtained. c. the living cyanobacterium Lyngbya subtilis and d. a collapsed filament from an axenic culture of Oscillatoria lad, e. living spiral filament of the cyanobacterium Arthrosopirs platensis showing beam damage and $\mathbf{f}$. living sample of axenic culture of type strain of microbial extremophiles Spirochaeta Americana, Hoover 2003. and f. (EDS spectral data at spot X shows N $=10.7 \%$ (atomic) and S = 0.4\% (atomic) and g. living EDS spectral data for other samples provided in Table 2.

\section{BIOGENIC ELEMENT RATIOS}

Table 2 provides the compilation of the elemental abundances measured for a number of the macrofossils and microfossils from carbonaceous meteorites, Archaean, Proterozoic and 
Phanerozoic rocks and Pleistocene, Holocene and living biological materials studied during this investigation.

TABLE 2. Biogenic Elements in Carbonaceons Meteorites, Archaean to Pleistorene Fossils, Holocene and Recent Diatoms and Cranobacteria

\begin{tabular}{|c|c|c|c|c|c|c|c|c|c|c|c|c|}
\hline FORMI & C & 0 & $\underline{\mathbf{N}}$ & $\mathbf{P}$ & $\mathbf{M g}$ & $\mathrm{s}$ & Si & Al & $\mathrm{Fe}$ & $\mathrm{COO}$ & $\mathbf{C N}$ & $\mathrm{CHS}$ \\
\hline Mnehiston_Matrix_laY & 62 & 50.1 & 16 & 0.3 & 7.5 & 2.6 & 10.8 & 0.9 & 6.1 & 0.12 & 3.8 & 2.4 \\
\hline Orgued_Matrix_3a8 & 39 & 69 & 0.0 & 04 & 06 & 41.4 & 1.2 & 0.2 & 44.1 & 0.6 & 27 & 0.1 \\
\hline Orguell_Manix_Balls_3a12 & 1.2 & 64 & 0.2 & 5.5 & 1.1 & 19 & 1.7 & 0.0 & 864 & 0.2 & 6.0 & 0.6 \\
\hline Mrarchison_Hormogon__aX & 41.7 & 168 & 65 & 1.2 & 7.4 & 6.1 & 185 & 0.4 & 6.4 & 2.5 & 83 & 6.4 \\
\hline Orgueil_Filament_2ax & 76 & 24.3 & 55 & 8,5 & 13.4 & 360 & 61 & 06 & 10.5 & 0.3 & 15 & 0.3 \\
\hline Orgneil Filament $3 \mathrm{~m}$ & 7.2 & 39.8 & 0.8 & 0.2 & 13.9 & 348 & 1.3 & 0.2 & 1.1 & 0.18 & 14 & 0.2 \\
\hline Orguell_Flameut_3a2 & 198 & 17.2 & $<5$ & 1.0 & 17.3 & 4.5 & 18 & 0.0 & 1.0 & 2.8 & 20 & 0.5 \\
\hline Orgueil_Filament_3a3 & 224 & 354 & 1.3 & 0.2 & 109 & 23.4 & 29 & 0.4 & 1.7 & 0.6 & 17.2 & 7.7 \\
\hline Orgnell_Slkeath_3aT & 465 & 200 & 1.0 & 0.8 & 74 & 88 & 12.1 & 1.4 & 1.2 & 2.3 & 20 & 5.3 \\
\hline Orgaeil_Filament_3n9 & 89 & 351 & 5 & 0.2 & 14.2 & 338 & 4.0 & 0.3 & 3.1 & 0.3 & 18 & 0.3 \\
\hline Orgneil_Sheath_3alo & 548 & 13.4 & $<5$ & 0.6 & 6.1 & 17.2 & 6.2 & 0.6 & 0.5 & 4.1 & $\$ 109$ & 3.2 \\
\hline Orgueil_Sheath_3an & 458 & 148 & $<5$ & 06 & 8.5 & 215 & 39 & 0.6 & 0.5 & 3.1 & $>91$ & 2.1 \\
\hline Orgueil_sheath_tax & 278 & 9.2 & $<5$ & 55 & 2.3 & 5.9 & 0.6 & 0.0 & 0.0 & 89 & 156 & 13.8 \\
\hline Orgneil_filament_4nY & 558 & 11.8 & 55 & 5 & 11.6 & 20 & 0.7 & 0.0 & 0.0 & 4.7 & $=111$ & 28 \\
\hline Karelian_Oscillatoria_5aX & 22.2 & 28.4 & 55 & 5.5 & 0.7 & 0.0 & 21.2 & 9.1 & 0.7 & 0.8 & 244 & $>44$ \\
\hline Karelian_Filament $5 \mathrm{eX}$ & 156 & 68 & $<5$ & 1.3 & 0.0 & 11.2 & 1.6 & 52.3 & 0.0 & 2.3 & 331 & 1.4 \\
\hline Brachyaspitien_Eye_6ax & 96 & 44 & $<5$ & $<5$ & 2.0 & 0.0 & 24.5 & 56 & 2.2 & 4.4 & 219 & 319 \\
\hline Peronopsis_interstricta_6bX & 9 & 40 & $<5$ & $<5$ & 1.6 & 0.0 & 4.5 & 2.5 & 49 & 0.2 & $>18$ & 218 \\
\hline Botogol_Orabitid_6dX & 304 & 15.8 & 5 & $<5$ & 55 & 55 & 269 & 119 & 3.5 & 1.3 & 41 & $\therefore=41$ \\
\hline Botogol_Filament_beX & 629 & 3.7 & 65 & 0.5 & 0.0 & 0.3 & 15.4 & 38 & 2.3 & 17 & -126 & 126 \\
\hline Knightan_Bom_6fC & 132 & 376 & $<5$ & 12.4 & 13 & 1.4 & 5.7 & 1.7 & 1.6 & 0.3 & 226 & 94 \\
\hline Vostok 1249M $7 \mathrm{aX}$ & 190 & 667 & 3.7 & $<5$ & $<5$ & 55 & 11 & 1.8 & 0.0 & 0.3 & 5.1 & -38 \\
\hline Vastok_1002M_Rhizo_7 $\mathrm{CX}$ & 33.6 & 351 & 65 & 55 & 1.5 & 55 & 151 & 58 & 0.9 & 1.0 & 52 & -67 \\
\hline Manumorl_guard_8aX & 704 & 156 & 11.9 & 0.0 & 0.1 & 1.5 & 02 & 00 & 0.0 & 4.5 & 5.9 & 469 \\
\hline Mrammoth_tissue_8eX & 594 & 268 & 48 & 0.1 & 07 & 04 & 6.3 & 0.0 & 0.7 & 2.2 & 12.4 & 150 \\
\hline Mummy_Hair_8dX & 64.4 & 196 & 10.7 & 0.0 & 0.1 & 1.8 & 0.2 & 0.0 & 0.0 & 3.3 & 6.0 & 36 \\
\hline 1816_Bangia_9aX & 679 & 219 & 71 & 0.2 & 0.1 & 0.5 & 1.7 & 0.0 & 0.0 & 3.1 & 9.6 & 136 \\
\hline 1816_Baugha_9aY & 624 & 22.4 & 9.3 & 07 & 00 & 1.0 & 3.1 & 0.2 & 0.0 & 2.8 & 6.7 & 624 \\
\hline 1816_Bangia $9 a Z$ & 270 & 46 & 3.4 & 01 & 0.0 & 0.8 & 17.4 & 0.5 & 0.0 & 0.6 & 79 & 338 \\
\hline 1834Schiz_lenormandi_96X & 50.0 & 304 & 10.2 & 0.0 & 0.0 & 83 & 8.5 & 09 & 0.0 & 1.6 & 4.9 & 100 \\
\hline 1834Schiz_lenormandi_9bY & 649 & 20.8 & 7.7 & 0.0 & 0.3 & $<5$ & 3.1 & 2,4 & 0.0 & 3.1 & 8.4 & 130 \\
\hline Lymgdnz_subnilis_yeX & 61.5 & 25.7 & 9.5 & 1.5 & 0.0 & $<5$ & 0.4 & 0.2 & 0.0 & 2.4 & 6.5 & 122 \\
\hline 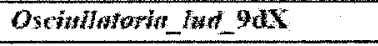 & 51.9 & 20.9 & 4.2 & 0.1 & 5.4 & 2.6 & 0.4 & 0.0 & 0.0 & 2.5 & 12.3 & 20 \\
\hline Inthrospita_platensis $9 \mathrm{eX}$ & 62.3 & 250 & 83 & 0.0 & 0.0 & 55 & 0.0 & 0.0 & 0.0 & 2.5 & 7.5 & 125 \\
\hline Spitochaeta_ameroranta_9n & 62.3 & 218 & 10.7 & 0.8 & 0.2 & 0.4 & 0.8 & 0.2 & 0.0 & 2.7 & 5.8 & 156 \\
\hline
\end{tabular}

The ratios of the biogenic elements $\mathrm{C} / \mathrm{N} ; \mathrm{C} / \mathrm{S}$ and $\mathrm{C} / \mathrm{O}$ ratios for the carbonaceous meteorites and terrestrial fossils (Archaean to Eocene) and the Pleistocene and Holocene hair, tissue and filaments Woolly Mammoths, predynastic Egyptian mummies and modern and living cyanobacteria, diatoms and other microbial extremophiles demonstrate. Although the $\mathrm{C} / \mathrm{O}$ ratios are not very helpful, it is clear that $\mathrm{C} / \mathrm{N}$ and $\mathrm{C} / \mathrm{S}$ ratios may be effectively used to distinguish between indigenous fossils and recent mierobiological contaminants. Plots of these biogenic ratios are shown in Figure 10. 


\section{C/N Ratio}

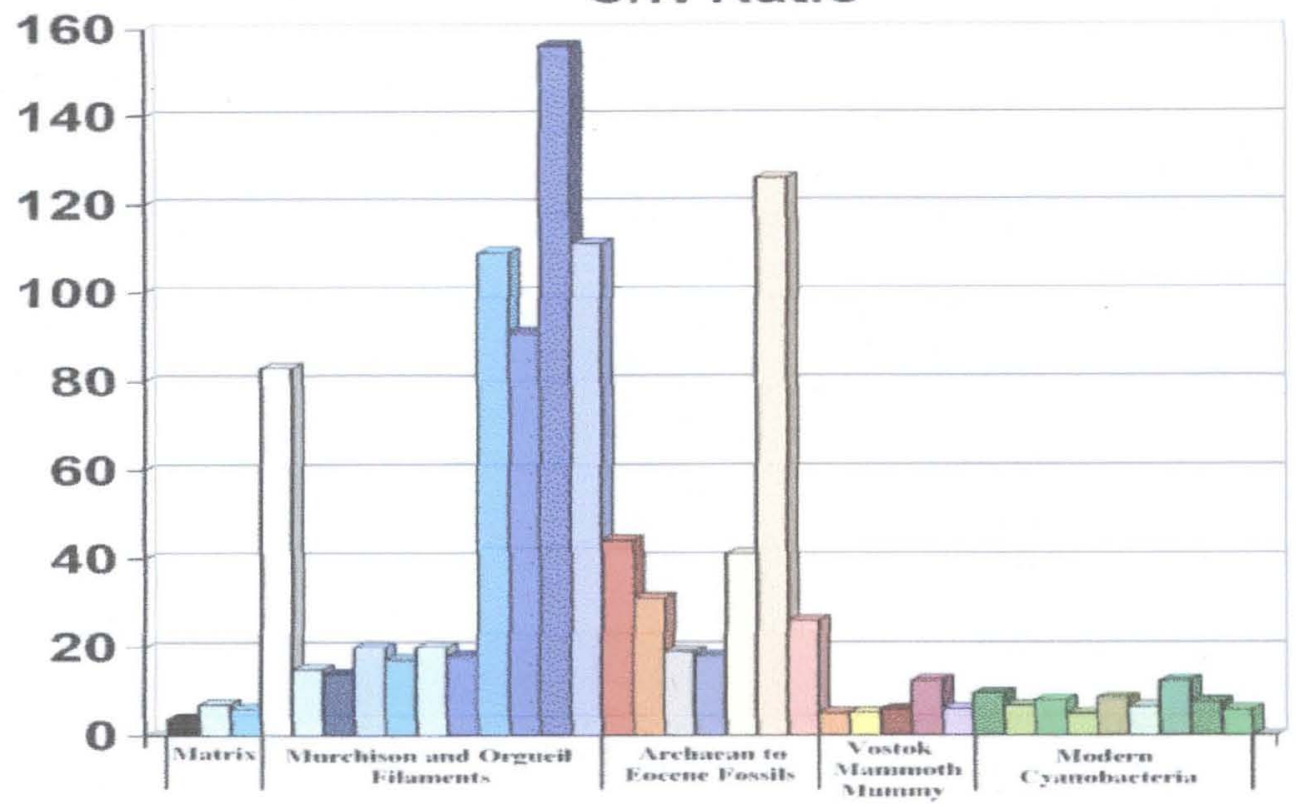

- lar Murchision Matri

O308_Orgined Ntatrix

OJa12 Orgest Matri.

D :ax_Murch_Harmogoen

Q 2ax_Orgueit_Filarnent

wa1_Or atsoit_Fitarment

Q3e2 Orgueil Fiament

03a3 Orgunis Fitarnent

Q $3 a 7$ Orguen Shoath

Q 3 a9 Orguen FHament

G3a10 Orauent sterath

mat1 Prouet steath

asex Orgureit stmato

eane crinon strom

a sax Karetiagncitator io

Q5eX Karetia Fiament

Q $5 \mathrm{a} \times$ BrachyosptdienEye

G5tx Peronopsito inder

G6dX Eotonol Orabitix

abex Eotogol Mito

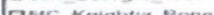

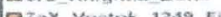

Q7ax_vamén

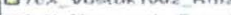

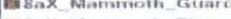

asex Mactimstotio Tissm

GBdx_Mtuminy_5000y"

G9ax 18 tobangia

Dear 18158sanoia

Bgaz 1816 gantia

a9hX 183aschizon

a9tr $18345 c h i z a n$

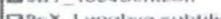

a

azan Osem_ud

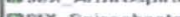

orix Spirochaet.

\section{C/S Ratio}

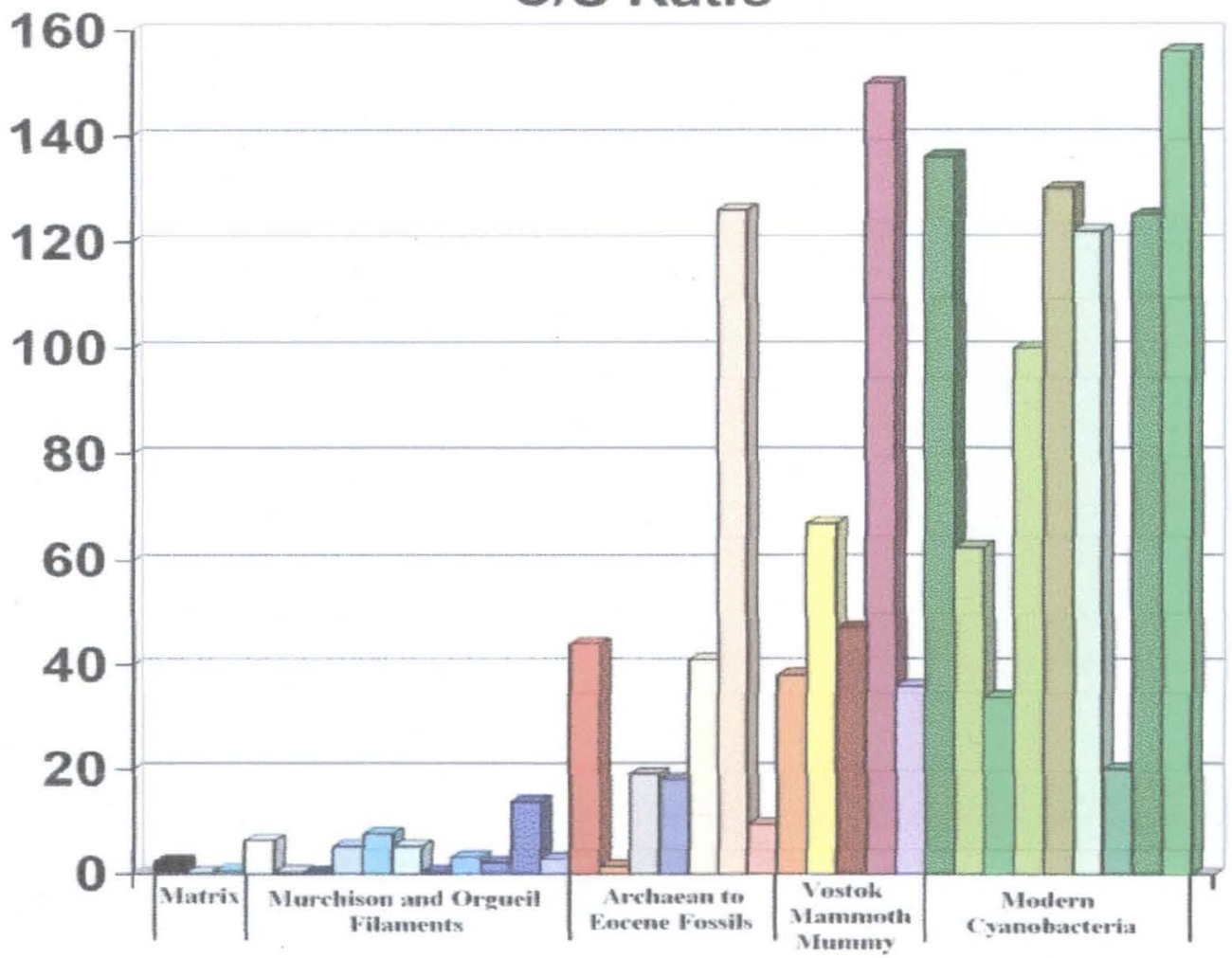

- 1aY Murchison Matrix Q3as Orgueit Matrix Q3a12 Orguen Matrix Dlax_Murch_Hormogone $02 a x$ Orgueit Filament m3at Orcueil Filament 03a2_Orgueil_fiament Q3a3 Orqueil Filament Q3a7 Orgueit Sheath a3as Orgueil Filament a3ato Orgueit Sheath a3at1 Orgueil Sheath E4ax Orgueil Sheath Q4ar Orgueil Filament a SaX KareliaOscitlatoria $05 c \times$ Karetia Filarnent a6ax BrachyaspidienEye a6bX Peronopsis inter. प6edX Betonol Orabitid rabex_Botogol_Mite 口6fC Knightia Bono G7ax Vostok 1249 Fil. D7cX Vostok 1002 Rhizo gax Mammoth Guard 口8cX_Mammoth_Tissue 口8dX Mutmmy 5000yo

a9aX 1816Bangia D9aY_1816Bangia Q日9az 1916Eangia 口9bx 1834schizon asby_1834Schizon Ca9cX Lyngtrya subtilis E8dX Oscill hud ageX Arthrospira G97X Spirochaeta 


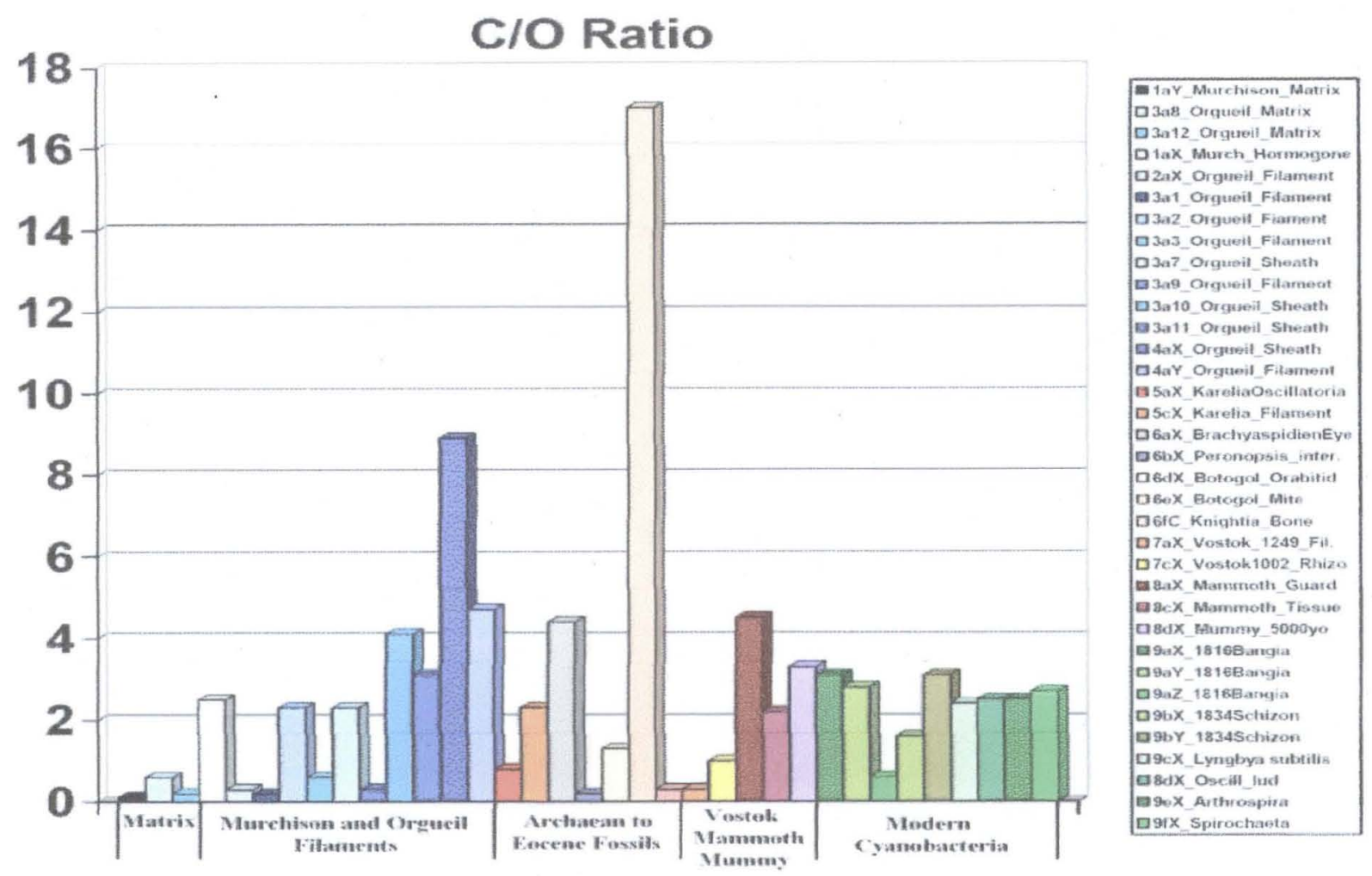

Figure 10. Plots of the $\mathrm{C} / \mathrm{N}, \mathrm{C} / \mathrm{S}$ and $\mathrm{C} / \mathrm{O}$ ratios for the fossils and living biological materials described.

A summary of the range of these biogenic element ratios is as follows:
$\mathrm{C} / \mathrm{N}$
$\mathrm{C} / \mathrm{S}$
C/O

Orgueil Filaments:

20 to $>156$

0.2 to 13.8

0.3 to 8.9

Archaean Filaments (Karelia)

31 to $>34$

1.4 to $>44$

2.3 to 4.4

Cambrian and Ordovician Trilobites

$>18$ to $>41$

$>18$ to $>41$

0.1 to 4.4

Devonian Microfossils \& Eocene Fish

$>41$ to $>126$

$>41$ to $>126$

1.3 to 82

Pleistocene/Holocene Hair

5.1 to 12.4

20 to 156

0.3 to 2.7

Although the FESEM EDS is not extremely sensitive to nitrogen, it is certainly capable of detecting nitrogen at the $0.5 \%$ level $(5,000 \mathrm{ppm})$, Under ideal conditions nitrogen can be detected as low as $0.2 \%(2,000 \mathrm{ppm})$ or less. Nitrogen levels as low as $0.2 \%$ were detected in the meteorite rock matrix and in a form interpreted as an akinete in the Orgueil meteorite. However, to be conservative the value $0.5 \%$ was used to avoid division by zero to determine minimum $\mathrm{C} / \mathrm{N}$ levels of Table 2 . EDS studies carried out with the same instrumentation have repeatedly demonstrated that the abundances of major biogenic elements found in the Orgueil filaments are distinctly different from that found in living organisms (bacteria, archaea, and cyanobacteria grown in axenic cultures, in enrichment assemblages, and in natural ecosystems), recently ( 190 years or less) dead prokaryotic and eukaryotic microorganisms (cyanobacteria and diatoms of the Grunow Collection, Henri van Heurck Museum), or in ancient ( 32,000 years) cryopreserved Pleistocene wood, moss, and bacteria from the Fox Tunnel of Alaska. The EDS analysis indicates that nitrogen is well above the level of detectability in all of the living and dead (herbarium material) cyanobacteria with abundances ranging from $4.6 \%$ to $12.6 \%$. Nitrogen was also undetectable in the fossilized cyanobacteria found in the proterozoic phosphorites of Khubsughul, Mongolia and in the archaean rocks of Northern, Karelia in Siberia. ${ }^{69-71}$

\section{CONCLUSIONS}

The striking feature about the Archaean filaments and the Cambrian, Ordovician, Devonian and Eocene fossils, as well as the forms interpreted as microfossils of filamentous prokaryotes in the Orgueil and Murchison 
meteorites is the almost universal absence of detectable nitrogen even though carbon is sometimes extremely abundant. However, the nitrogen levels detected in long dead biological materials (ancient filaments from Vostok ice cores, Woolly Mammoth hair, and a large number of hair and tissue samples from ancient mummies from Egypt and Chile) are not notably different from those found in living and recently dead cyanobacteria and other biological materials. The CIS ratios of many of the meteorite filaments, and known terrestrial fossils are also clearly distinguishable from modern and Pleistocene biological materials

\section{ACKNOWLEDGEMENTS}

I am grateful for the Electron Microseopy support provided by Gregory Jerman and James Coston of the NASA Marshall Space Flight Center that made this research possible. I also want to thank Dr. Paul Sipiera and the James M. DuPont Meteorite Collection of the Planetary Studies Foundation, Chicago, Illinois, and Dr. Martine Rossignol-Strick and Dr. Claude Perron and the Meteorite Collection of the Musee Nationale d'Histoire de Paris for providing the Orgueil meteorite samples, I atso thank Dr. Rosemarie Rippka of the Pasteur Institute (Paris), Academician Georgy Zavarzin and Dr. Ludmila M. Gerasimenko of the Institute of Microbiology, RAS (Moscow) and Dr. Sam van Landingham for many helpful discussions about the morphology and characteristics of cyanobacteria in natural environments and axenic cultures. I thank Dr. Ann St. Amand of Plyeotech, Frc. Michigan for environmental samples of Calothrix and other living cyanobacteria and the late Dr. Walter van den Bergh of the Henri van Heurck Museum in Antwerp, Belgium for herbarium samples of early type algal material. I am grateful to Prof. A. Yu. Rozanov and Dr. M. M. Astafieva of the Institute of Paleontology, Russian Acaderny of Sciences, Moscow for helpful discussions concerning fossil cyanobacteria and samples of archaean rocks from Northern Karelia and Acadenician Erik Galimov for helpful discussions concerning metcorites and biological fractionation. I also acknowledge the funding support provided by the NASA/MSFC Center Director's Discretionary Fund; the NASA Astrobiology Institute and the NASA/JSC Center for Binmatkers in Astromaterials, which has made this research effort possible.

\section{REFERENCES}

1. S. Cloez, "Note sur la composition chimique de la piente néteonique d'Orguein", Compt, Rend. Acad. Sct. 39, 37-40. 1864.

2. S. Cloez, "Analyse chimique de la plerte météorique d'Ofgued", Compt. Rend. Acad. Sci. 59, 37-40. 1864.

3. F. Pisani, "Etude chimique et analyse de l'aerolithe d"Orgneil", Compt Rend. Acad Sci. 59, 132-135, 1864.

4. M. Berthelot "Sur la Matiere charboneuse des meteonites." Compt. Rend. Acod. Scir, 67, 849, 1868.

5. B. Nagy, W. G. Meinschein, D. J. Hennessy, Mass spectroscopic analysis of the Otgueil meteorite: evidence for biogenic hydrocarbons Amn. N. Y. Acad. Sci., 93, 27-35, 1961.

6. K. A. Kvenvolden, J. G. L.awless, K. Pering, E. Peterson, J. Flores, C. Ponnamperuma, I. R. Kaplan and C. Moore, "Evidence for extraterrestrial amino acids and frydrocatbons in the Murehison motertite, Nature 228, 923-926, 1970.

7. K. A. Kvenvolden, J. G. Lawless, and C. Ponnampetuma, "Non-protein atnitro acids in the Murchison meteorite", Proc. Natl. Acad. Sei. U.S.A. 68, 486-490, 1971.

8. B. Nagy, and M. C. Bitz, "Long-chain fatty acids in the Orgueil metcorite" Arch. Biochem Biophys, 101, 240248,1963 .

9. G. W. Hodgson, and B. L. Baker, "Evidenee for porphyrins in the Orgtieil meteorite" Nature 202, 125-131, 1964.

10. G. W. Hodgson and B. Baker, "Porphyrins in meteorites: metal complexes in Orgueil, Murray, Cold Bokkeveld and Mokoia carbenaoeous ohondrites", Geochim, Cosmachim Acta 33, 943-958, 1969.

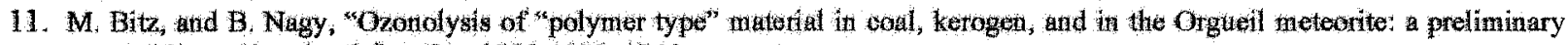
report." Proc. Nat. Acad. Sei. 56, 1383-1390, 1966.

12. B. T. Commins and I. S. Harrington, "Polycyclic aromatic hydrocarbons in carbonaceons meteorites." Nature, 212, 273-274, 1966.

13. D. W. Nooner and J Ores, "Organic Compounds in Meteorites, 1. Aliphatic Hydrocatbons." Geochimt Cosmochum. Acta 31, 1359-1394, 1967 .

14. E. Gelpi and J. Oro, "Organic compounds in meteorites-IV. Gas chromatographic-mass spectrometric studies on the isoprenoids and other isomeric alkanes in oarbonaceons dhondrite s." Geachin. Casmochim. Acta 34, 981-994, 1970.

15. R. Hayatsu, R., "Orgueil meteorite: organic nitrogen content s" Science 146, 1291-1293, 1964.

16. R. Hayatsu, M. H. Studier, L. P. Moore and E. Anders, "Purines and Triazines in the Murehison meteorite", Geochim. Cosmochim. Acta 39, 471-488, 1975 . 
17. C. E. Folsomme. J. Lawless, M. Romiez, and C. Ponnampenuma, "Heterocyclic compounds indigenous to the Murchison meteorite", Nature 232, 108-109, 1971.

18. L. L. Hua, K. Kobayashi, E. I. Oehai, C. W. Gerke, K, O. Gerhardt, and C. Ponnampenima, Identification and quantification of nucleic acid bases in carbonaccous chondrites, Orgins of Life 16, 226-227, 1986.

19. P. G. Stoks, and A. W. Schwarte, Nitrogen-heterocyclic compounds in meteorites: significance and mechanisms of formation," Geochim Cosmochim Acta 45, 563-569, 1981.

20. Y. V. Kissin, "Hydrocabon components in carbonaceous meteorites." Geachim. Cosmochim. Acta 67, 1723-1735, 2003.

21. J Oro, $\mathrm{S}$. Nakaparkin, $\mathrm{H}$. Lichtenstein, and E. Gil-Av, "Configuration of amo acids in carbonaceous chondrites and a PreCambrian chert." Nature 230, 107-108, 1971.

22. J. Oro, J. Gilbert, H. Lichstein, S. Wikstrom, and D. A. Flory, "Anino acids, aliphatic and aromatic hydrocarbons in the Murchison meteorite", Nature, 230, 105-106, 1971.

23. M. Engel and B. Nagy, "Distrbution and enantionetic compostion of amino acids in the Murchison meteorite," Nature 296, 837-840, 1982.

24. M. H. Engel, S. A. Macko, and I. A. Silfer, "Carbon lsotope composition of individual anino acids in the Murchison neteorite," Nature 348,47-49, 1990.

25. M. H. Engel, and S. A. Macko, "Stable isotope analysis of aniwo acid enantiomets in the Murchison meteorite at natural abundance levels", Instruments, Methods, and Missions for the Investigation of Extraterrestrial Microorgantsms, (R. B. Hoover, Ed.), Proc. SPE, 3111, 82-86, 1997 .

26. M.H. Exgel and S. M. Macko, SA. "Isotopic evidene for extratertestral non-zacemic anino acios in the Marchison meteorite." Natare 389, 265-268, 1997.

27. M. H. Engel, V. E. Andras, and S. A. Macko, "Amino Acids as Probes for Life's Origin in the Solar System." in Perspectives in Astrobiology, Vol. 366, NATO Scienoe Sories: Lfo and Behavioural Seiences (R. B. Hoover, R. Paepe, and A. Yu. Rozanoy, ds.) IOS Press, Amsterdan, The Netherlatids, pp. 25-37.

28. J. R. Cronin and S. Pizzarello, "Enantiomerie Excesses in Meteoritie Amino Acids", science, 275, $951-955$, 1997.

29. P. Ehrenfreund, D. P. Glavin, O. Botta, G. Cooper, and J. L. Bada, "Extraterrestrial amino acids in Orgueil and Ivuna: Tracing the parent boty of Cl type carbonuceous chondrites,"Phoc Nat Acot Sck, 98, 2138-2141, 2001 .

30. E. Pierazzo, and C. F. Chyba, "Cometary delivery of biogenic elements to Furopa," lcoras, 157, 120-127, 2002.

31. Space Studies Board, "The Cosmic History of Biogenic Elements and Compounds. In The Search for Life's Origins: Progress and Future Directions in Panetary Biology and Chemical Evolution." National Academy of Sciences Commission on Physical Sctences, Mahlowatios, and Applications, Nattond Academy Preds, pp. 21-5s, 2000.

32. B. Magon, "The carbonaceous chondrites:"Space Sct. Rev, 1, 621-646, 1963.

33. W. Otting, and J., Zahringer, J.s "Total Carbon content and primordial tare gases in chondrites." Geochim Cosmochim Acto 31, 1949-1960, 1967 .

34. $M$. Perrean, $C$, Engrand, $M$, Maurette, $G$, Kurat, and $T$. Presper, "C/O Atomie ratios in micrometer-sized crushed grains from Antarctio micrometeorites and tho carbonaceous tneteontes." 1CPS XXIV, Lunar and Planetary Institute, $1125-1126$, 1993.

35. H. Lodish, D. Baltimore, A. Berk, L. 3. Zipursky, P. Matsudaira, and I Darnel, Molecular Cell Biology, Third Edition, Scieutific Amorican Books, New York, pp. 1-1344, 1997

36. S. A. Mtcko, M. D. Uhle, M. I. Engt, und V. Andrusevich, “gtable nitrogen isotope analysis of amino acid enantiomers by gas chromatography/combustion/ssotope ratio mass spectrometry. Analytical Chemisfy, 69, 926-929, 1997.

37. J. M. Hayes, I. R. Kaplan, K. W. Wedeking. K. W. "Precambrian Organic Geochemistry, Preservation of the Record" In Earth's Earliest Bowphere: Its Origh and Evolution, (J. W. Sehopf, Ed, Princeton Univ, Press, 93-132, 1983.

38. M. W. Walter, "Archaean Stromatolites: Evidence of the Earth"s Earliest Benthos" In Eapth's Eartiest Biosphere: its Origin and Evolufion, (I. W. Schopf, Ed.) Princeton Univ. Press, 187-212, 1983.

39. M. Schidlowski, “A 3,800 million-year-old record of life from carbon in sedimentary rocks, Nature, 333,313 $318,1988$.

40. M. Sehidowski, M. "Carbon isotopes as biogeochenical roconders of life over 3.8 Ga of Earth history" evolution of a concept" Precambrian Research, 106, 117-134, 2001.

41. J. W. Schopf, "The Fossil Record: Tracing the Roots of the Cyanobacterial Lineage" In The Ecology of Cyanobacteria: Their Diversify in Time and Space (B. A. Whitton and M. Potts, Eds; Klewer Academi, Dordrecht pp. 13-35, 2000.

42. J. Wing; "Simultaneous defenmination of Oxygen and sillow in meteotites and rocks by non-destructive activation analysis by fast nettrons." Anal Chem. 36, 359-364, 1964.

43. L. Stal, "Cyanobacterial Mats and Stromatolites. "In The Ecology of Cyanobacteria: Their Divensity in Time and Space. (B. A. Whitton and M. Potts, Eds.) Klewer Acadenic Publishers, Dordreclit pp. 61-112, 2000.

44. B. Nagy Canbonaceows Meteontes, Fisevier Sciontifio Publishing Co., Now York, 1-747, 1975.

45. B. Mason, "The carbonaceous chondrites." Space Bct Rey, 1, 621-646, 1963.

46. C. B. Moore, "Nitrogen, 7" In B. Mason (Ed), Handbook of Etemental Abundances in Meteorites, Gordon and Breach, New York, N. Y, pp. 93-98, 1971. 
47. E. K. Gibson, C. B. Moore, and C. F. Lewis, "Total Nitrogen and Carbon abundances in carbonaceous chondrites." Geochem. Cosm. Acta, 35, 599-604, 1971.

48. J. -P, Gallien, L. Orgerger, L. Datidin, D. L. Pinti, and J. Pasava, "Nitrogen in biogenic and abiogenic minerals from Paleozoic black shales in NIA study." Nuclear Instr and Meth in Phys. Res B., 217, 113-122, 2004.

49. R. W. Castenholz, R. Rippka, R and M. Herdman, "Form Genus VII. Microcoleus Desmazières 1823" in Bergey's Manual of Systematic Bacteriology. Volume One. The Archaed and the Deeply Branching and Phototrophic Bacteria (Boone, D. R., Castenholz, R. W. and Garrity, G M, Eds.). Springer-Verlag, New Youk, N.Y. pp. 548-550. 2001.

50. K. Anagnostidis, "Nomenclatural changes in cyanoprokaryotie order Osctllatoriales." Presha, Praha, 73, pp. 359-375, 2001

51. L. Geitler, L. "Synoptische Darstelung der cyanophyceen in morphologischer und systematischer Hinsicht" Beih. Bot. Zantralbl., 41, pp.163-294. 1925

52. T. V. Desikachary, Cyanoplyzta, Academic Press, New York, pp. 1-686, 1959.

53. V, N, Kozhemikov, "Archaean greenstone belt of the Karelian oraton as accretionary orogens." Petrozavodsk: Karelian Research Centre, Russian Academy of Science, pp. 1-223, 2000.

54. M. M. Astafieva, R. B. Hoover, A. Yu. Rozanov and A. B. Vrevskiy, A. B., "Fossil Microorganisms in Archaean deposits of Northem Karelia" Astrobtology and Planefary Misstons, SPIE, 5906, 06 1-6, 2005.

55. R. A. Robison, "Additional Middle Cambrian Tritobites from the Wheter Shale of Utah," I. Faleontology 45, 796-804. 1971.

56. R. R. Gaines and M. L. Droser, "Paleoecology of the familiar trilobite Elrathia kingii: An Early exaerobic zone inhabitant," Geology 11, 941-944, 2003.

57. M. N. Rees, "A fault controlled trough through a carbonate platform the Midde Cambrian House Range embayement," Geol. Soc. Amer, Bull 97, 1054-1069, 1986.

58. S. I. Zhumur, A. Yu. Rozanov, R. V. Lobzova, and E A. Zhegallo, "About resource of carbon of graphite ores of Botogol syente massif (East Sayan)", Moscow, DAN RAN, Ser. Geol, 348, 3, 360-362, 1996.

59. A. Rozanov, Zhegallo E.A, and R. B. Hoover, "Mictobiotu of the Botogol graphites", SP1E, 3755, 38-46, 1999.

60. S. S. Abyzov, N. E. Bobin, and B. B. Koudryashov, B.B. Microbiological flora as a function of ice depth in central Antarctica." in Life Sciences and Space Reseanch, Oxford, pp. 99-103. 1979.

61. S. S. Abyzov, "Microorganisms in the Antarctio loc" Antarctic Microbiology, ed. by E I. Friedmann, WilleyLiss Lne., New York pi. 265-295, 1993.

62. S. S. Abyzov, R. B. Hoover, S. Imura, S., I. N. Mitskevich, T. Naganuma, M. N. Poglazova, and M. V. and Ivanov, M. V., Use of Different Methods for Discovery of lee-Entrapped Mcroorganisms in Ancient Layers of the Antarctic Glaciex."Advances in Space Research Cospar, 33, 1222-1230, 2004.

63. N. Ingram Hendey, "An Introductory Account of the Smaller Algae of the British Coastal Waters, Part V: Bacillariophyceae (Diatoms)" Landon: Her Majesty's Stationery Office, p. 145, 1964.

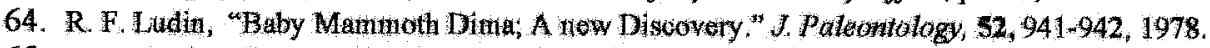

65. F. T. Kutzing, Spectes Algarum, F. A. Brookhaus, Lipsia, 1-922, 1849.

66. R. B. Hoover, "Those Marvelous Myriad Diatoms, National Geographic, 159, 870-878, 1979.

67. R. B. Hoover, F. Hoyle, N. C. Wickramasinghe, M. J. Hoover, and S. Al-Muft, "Diatoms on Earth, Comets, Europa, and in Interstellar Space," in Asronomical Origin of Life: Steps Towatd Panspermia, (Fred Hoyle and N C. Wiekramasinghe, Eds., pp. $197-224,2000$

68. R. B. Hoover, E. V. Pikuta, A. K. Bej, D. Marsic, W. B. Whitman, J. Tang, and P. Krader, "Spirochaeta americana sp. nov., a new haloalkaliphilic, obligately auacrobic spiroehaete isolated from soda Mono Lake in California" Ini. J. Syst. Evol. Microbial. 53, 815-821, 2003.

69. M. C. Stortie-Lonbardi and R. B. Hoover, "Fossil signatures Using Dlomental Abundance Distributions and Bayesian Probabilistic Classification." Instruments Methods and Missions for Astrobiology, VIII, Hoover, R. B., Rozanov, A. Yu. and Levin, Gil, Eds;), Proc. SPIE 5555, 18-30, 2004.

70. A. St. Amand, Ann, R. B. Hoover, G. Jerman, J. Coston, ant A. Yu. Rozanov, "Morphology und elemental conposition of recent and fossil cyanobacteria." Astrobiology and Ptaneary Missons, SPIE, 5906, 03 1-17, 2005.

71. M. M. Astafieva, R. B. Hoovor, A. Ya. Rozanov, and Vrevskiy, A. B., Fossil Microorganisms in Archaean deposits of Northem Karelia." Atrobiology and Planetary Missions, SPIE, 5906, 06 1-6, 2005. 